2nd International Conference on Natural Products and Physiologically Active Substances (ICNPAS-2004] 3rd EuroAsian Heterocyclle Meeting (EAHM-2004) "Heterocycles in Organic and combinatorial Chemistry" molecules

ISSN 1420-3049

http://www.mdpi.org

\title{
The Preparation of New Phosphorus-Centered Functional Groups for Modified Oligonucleotides and Other Natural Phosphates
}

\author{
Arnaud Gautier, Chrystel Lopin ${ }^{\#}$, Goulnara Garipova ${ }^{\ddagger}$, Olivier Dubert ${ }^{\S}$, Irina Kalinina", \\ Carmen Salcedo, Sébastien Balieu, Stéphane Glatigny, Jean-Yves Valnot, Géraldine Gouhier \\ and Serge R. Piettre*
}

Laboratoire des Fonctions Azotées et Oxygénées Complexes, UMR CNRS 6014, IRCOF-Université de Rouen, Rue Tesnières, F-76821 Mont Saint Aignan, France.

* Author to whom correspondence should be addressed; e-mail: $\underline{\text { Serge.Piettre@ } u \text { univ-rouen.fr }}$

Received: 23 April 2005 / Published: 30 September 2005

\begin{abstract}
Efforts to develop synthetic methodologies allowing the preparation of $\alpha, \alpha-$ difluorophosphonothioates, $\alpha, \alpha$-difluorophosphonodithioates, $\alpha, \alpha$-difluorophosphonotrithioates, and $\alpha, \alpha$-difluorophosphinates are reviewed in the light of applications in the field of modified oligonucleotides and cyclitol phosphates. Two successful approaches have been developed, based either on the addition of phosphorus-centered radicals onto gem-difluoroalkenes or on a process involving the addition of lithiodifluorophosphonothioates 91 onto a ketone and the subsequent deoxygenation reaction of the adduct. The radical route successfully developed a practical route to $\alpha, \alpha$-difluoro- $H$-phosphinates which proved to be useful intermediates to a variety of phosphate isosters. The ionic route led to the first preparation of phosphonodifluoromethyl analogues of nucleoside3'-phosphates.
\end{abstract}

Keywords: Phosphate isoster; difluorophosphonates; difluoro- $H$-phosphinates; nucleotide analogue; cyclitol analogue.

\footnotetext{
\# Present Address: Institut de Chimie Organique et Analytique, UMR 6005 CNRS, Université d'Orléans - UFR de Sciences, rue de Chartres, B. P. 6759, F - 45067 Orléans cedex 2, France.

$\ddagger$ Present Address: Laboratoire de Chimie Macromoléculaire, UMR 7610 CNRS, Université Pierre et Marie Curie, 4 Place Jussieu, F - 75252 Paris cedex, France.

I Present Address: Department of Chemistry, University of California, Riverside, CA 92521-403, USA.

$\S$ Present Address: Department of Chemistry, Loughborough University, Leicestershire LE 11 3TU, UK.
} 


\section{Introduction}

The ubiquitous presence of the phosphate group in molecules involved in life processes has focused the attention of many organic and medicinal chemists in their efforts to design and generate non natural molecules to interfere with biochemical transformations. The phosphate group is mainly found in biomolecules in the form of its monoesters 1 or diesters 2 (Scheme 1), which are produced and broken down by the action of enzymes such as kinases, phosphorylases, phosphatases or nucleases, for instance. Hence the early design of efficient enzyme inhibitors has often relied on the use of phosphonates 3a, in which the esterified oxygen atom of the phosphate is replaced with a $\mathrm{CH}_{2}$ unit [1]. The pioneering work of Blackburn and McKenna in the early eighties resulted in the design and use of the $\alpha, \alpha$-difluoromethylphosphonates $\mathbf{3 b}$ as closer isosters of the phosphate [2]. Structural and electronic studies by Chambers and O'Hagan on the zwitterionic species 6 have since then confirmed this fact and firmly established the monofluorophosphonates and difluorophosphonates as closely related, hydrolytically and enzymatically stable mimics of the phosphate (Table 1) [3].

\section{Scheme 1}<smiles>[R]P(=O)(O)O</smiles>

1<smiles>[R]OP([R])(=O)O</smiles>

2
<smiles>[R][Z10](=O)(O)O</smiles>

3a: $X=H$ 3b: $X=F$<smiles>[R][Z10][R](=O)(O)[R4][R]</smiles>

4a: $X=Y=H$ 4b: $X=F ; Y=H$

Thus, the $\mathrm{pKa}_{2}$ as well as the bond lengths and angles obtained from $\mathrm{X}$-ray crystallography for the various functional groups clearly indicated the closer analogy between both $\mathbf{6 c}$ and $\mathbf{6 d}$, on the one hand, and the phosphate $\mathbf{6 a}$, on the other hand. Indeed, the literature reports numerous examples of enzyme inhibitors encompassing the above fluorinated phosphonates. Among these, analogues targeting phospholipase C (PLC), purine nucleoside phosphorylase (PNP) and protein phosphotyrosine, phosphoserine or phosphothreonine phosphatases have been published [4]. This functional group has also been successfully used to mimic the phosphate in nucleotide monophosphates and trisphosphates: analogues of adenosine monophosphate, cyclic adenosine monophosphate, adenosine triphosphate and adenosyl adenosine triphosphate, as well as structurally related potent inhibitors of the reverse transcriptase of Human Immunodeficiency Virus (HIV), have been described in literature [5]. 


\section{Table 1.}

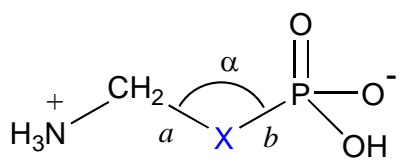

6

\begin{tabular}{cccccccc}
\hline Entry & Compound & $\mathbf{X}$ & $\alpha\left(^{\circ}\right)$ & $\boldsymbol{a}$ & $\boldsymbol{b}$ & $\boldsymbol{a}+\boldsymbol{b}$ & $\mathbf{p K a}_{2}$ \\
\hline 1 & $\mathbf{6 a}$ & $\mathrm{O}$ & 118.7 & 1.43 & 1.59 & 3.02 & 6.4 \\
2 & $\mathbf{6 b}$ & $\mathrm{CH}_{2}$ & 112.1 & 1.807 & 1.51 & 3.32 & 7.6 \\
3 & $\mathbf{6 c}$ & $\mathrm{CHF}$ & 113.3 & 1.82 & 1.50 & 3.32 & 6.5 \\
4 & $\mathbf{6 d}$ & $\mathrm{CF}_{2}$ & 116.5 & 1.85 & 1.496 & 3.35 & 5.4 \\
\hline
\end{tabular}

In the case of phosphate diesters 2, the replacement of both esterified oxygen atoms with two methylene units generates a phosphinate 4a, a functional group which has been used in the past to generate analogues of the natural parent phosphates. (Scheme 1) [6].

Our interest in new variants of the phosphonates led us to develop efficient preparations of the $\alpha, \alpha$-difluorophosphonothioate 5a, $\alpha, \alpha$-difluorophosphonodithioate $5 \mathbf{b}$ and $\alpha, \alpha$-difluorophosphonotrithioate 5c, in which the various oxygen atoms of the parent phosphonate become replaced with sulfur. More recently, we have focused on the phosphinate functional group, and the hitherto poorly developed fluorinated analogues $\mathbf{4 b}$.

Among the many possibilities for application are the antisense and antigene strategies, and the inositol cycle. Briefly, the antisense and antigene strategies rely on the formation of a triplex between the DNA and a modified oligonucleotide (MON), and of a duplex between the messenger RNA ( $m-$ RNA) and a MON, respectively, to keep the transcription (antigene) or the translation (antisense) from occurring (Scheme 2) [7]. This should result in the regulation of gene expression and open the door to a conceptually new therapeutic treatment of diseases. Analysis of the requirements for an optimal analogue of the monomeric unit in MONs points the finger at the necessity to keep the 3'-endo conformation 7 of the ribose cycle that favors pairing of the strands (Figure 1), an optimal geometry and electronic features of the phosphate mimic, and a stability towards the action of nucleases; this allows the MON to target another molecule of $m$-RNA molecule, once the first one has been lyzed by enzymes (antisense strategy; 4'-endo conformation).

\section{Figure 1}


7
$\mathrm{C}_{3^{\prime}}-$ endo

$$
\begin{gathered}
8 \\
\mathrm{C}_{2},-e x O
\end{gathered}
$$




\section{Scheme 2}

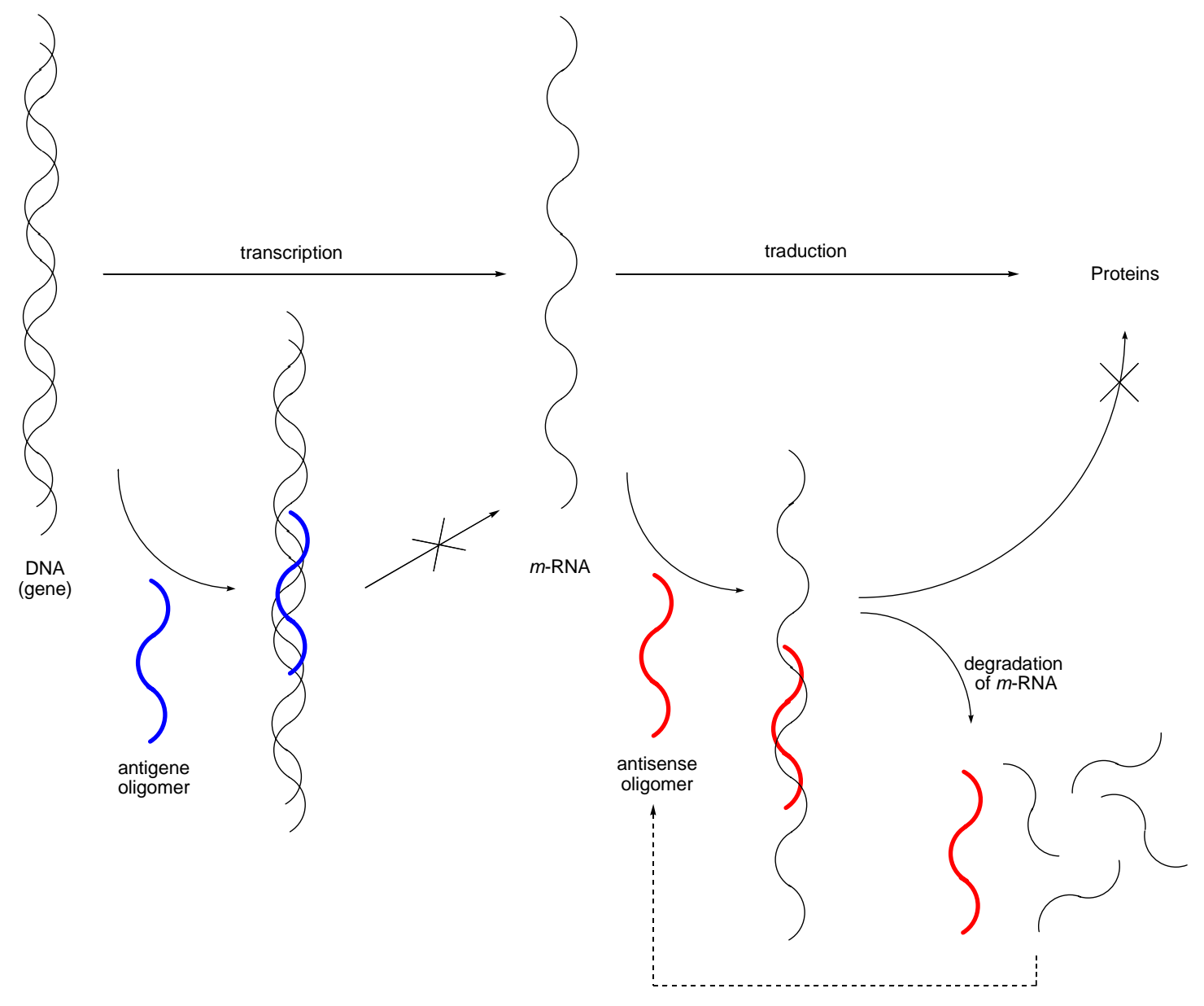

Numerous studies aiming at understanding the inositol cycle have underlied its importance [8]. The cycle is part of an important cell signalling system which helps regulate the intracellular calcium level. A very simplified view of the cycle (Scheme 3) shows how the second messenger inositol-1,4,5trisphosphate $\left(1,4,5-\mathrm{IP}_{3}\right)$ released from phophatidylinositol-4,5-diphosphate $\left(\mathrm{PIP}_{2}\right)$ by the action of a phospholipase $\mathrm{C}$, undergoes a sequential series of phosphorylations of the hydroxyl groups and hydrolysis of the phosphates to produce, among others, three different inositol monophosphates (I-4P, I-3-P and I-1-P). These are hydrolysed by a single enzyme, inositol monophosphatase (IMPase) to yield myo-inositol which is then converted into $\mathrm{PIP}_{2}$, thereby closing the cycle. Inositol monophosphatase is a homodimeric enzyme and has been postulated as a possible target to treat manic depressive illness [9]. 
Scheme 3

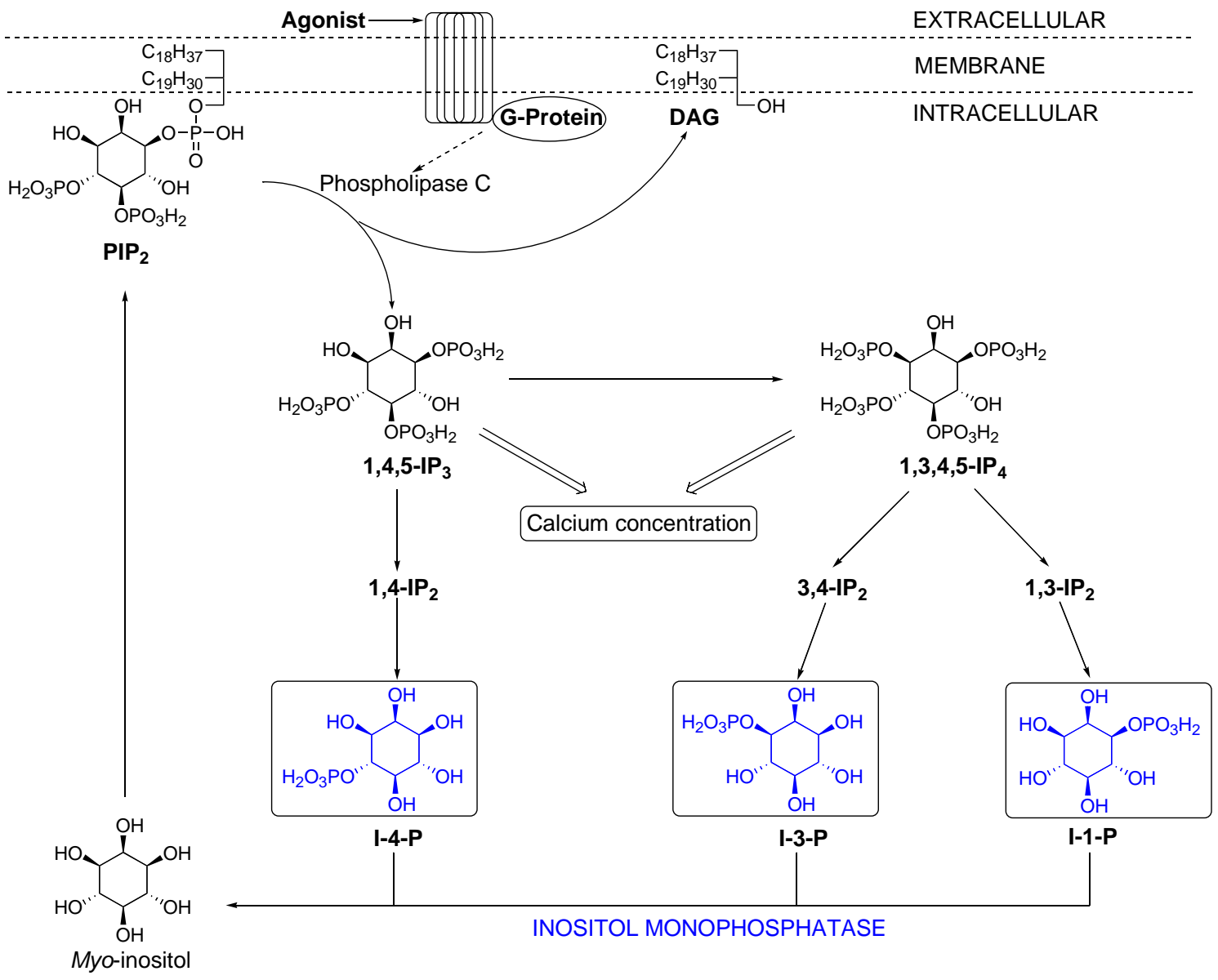

\section{Results and Discussion}

The target molecules we elected to work on are depicted on Figure 2. Thus both inositol-3phosphate 9 and nucleoside-3' phosphate 10 can be related to analogues 11 and 12, respectively, encompassing phosphono(thio)difluoromethyl units.

\section{Figure 2}

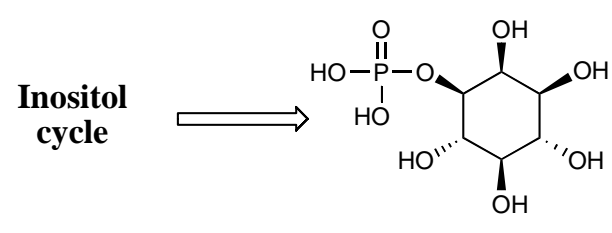

Inositol-3-phosphate

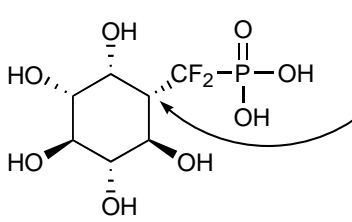

11a

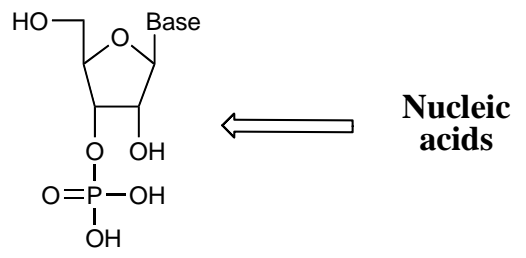

Nucleoside-3'-phosphate

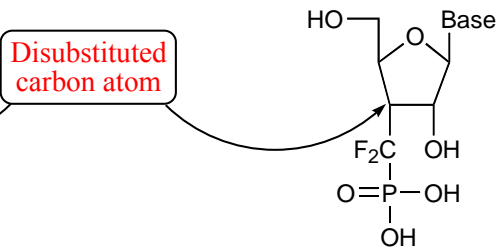

12a 
A particular feature of these molecules is the disubstitution of the carbon atoms bearing the $\mathrm{CF}_{2}$ moiety. A number of methodologies allowing the preparation of compounds characterized by this particular substitution pattern have been published and are outlined in Scheme 4 [10]. Early on, we chose to develop our own radical approach, and to use Berkowitz methodology relying on the sequential addition of phosphonodifluoromethyl anion on ketone and radical mediated deoxygenation process of the adduct.

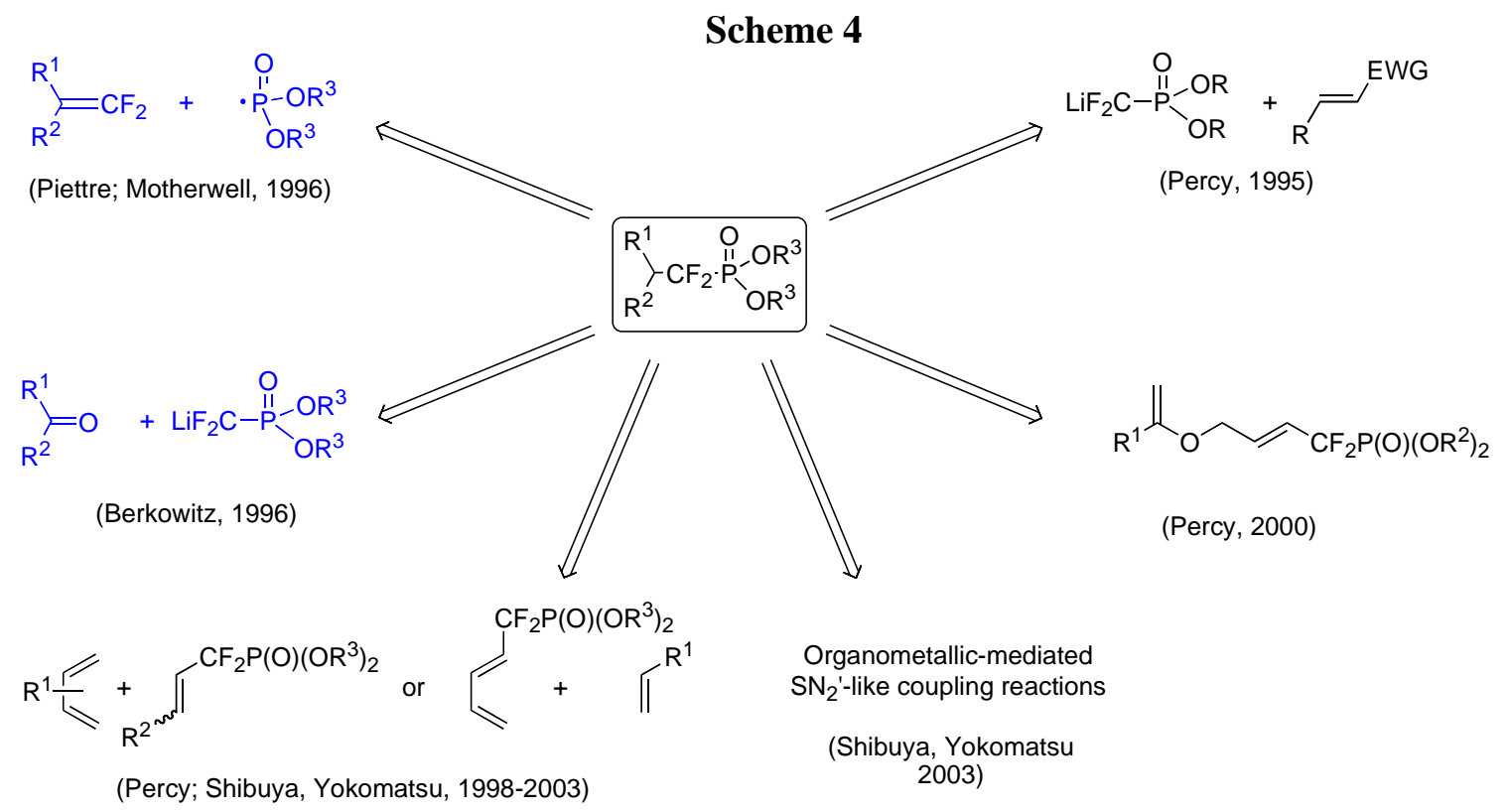

\section{A) MONS}

\section{a)_Radidical approac므.}

Retrosynthetic analysis of the target nucleoside-3'-phosphate analogues 12 pointed the finger at the probable wrong stereodirecting effect of the purine or pyrimidine base in the hydrogen quench of the radical adducts $\mathbf{1 5}$ generated from the addition of phosphonyl or phosphonothioyl radicals $\mathbf{1 3}$ onto difluoroalkene 14 (Scheme 5); this would produce the undesired phosphono(thio)difluoromethyl derivative 16. Hence it was decided to start from a carefully protected furanose derivative 19. A 1,2isopropylidene protecting group was chosen to take advantage of the steric hindrance generated by the angular methyl group and thus favor the formation of the desired diastereomer 18 [11]. 


\section{Scheme 5}



For synthetic purposes, phosphonyl 13a and phosphonothioyl 13b radicals are usually generated either from the corresponding phosphite 21a and thiophosphite 21b, respectively. These radicals, along with phosphonodithioyl 13c and phosphonotrithioyl 13d radicals, can also be produced from the selenophosphate derivatives 22 (Scheme 6) [111,12].

\section{Scheme 6}

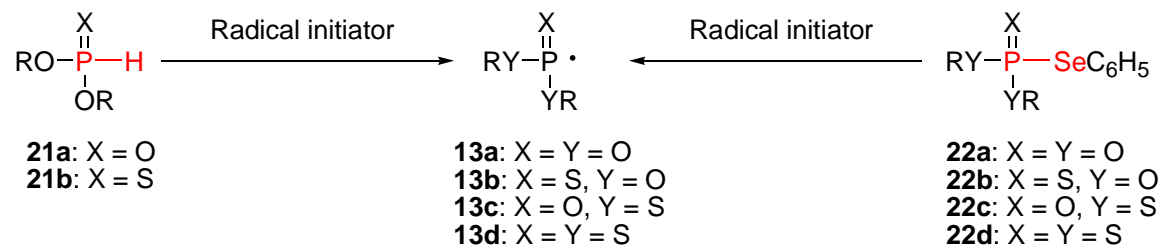

Radicals 13a and 13b have been shown to add onto $\beta, \beta$-disubstitued- $\alpha, \alpha$-difluoroalkenes under radical-chain conditions to yield the expected adducts in fair to good yields [10b-c, 10h, 10j]. The use of thiophosphite usually results in the formation of adducts in substantially higher yields (when compared to phosphites). Radicals 13c and 13d, however, were found to be unreactive towards these substrates.

In our case, the readily available glucofuranose derivative $\mathbf{2 3}$ was selected as starting material and oxidized into 24 [13], which was then conveniently transformed into the corresponding difluoroalkene 25 using literature methods (Scheme 7) [14]. However, attempts to add phosphorus-centered radicals 13 onto this substrate by either method completely failed to furnish the desired adducts 26, the substrate being recovered [15]. Other cyclic difluoroalkenes (e.g. 19, 27 and 28) displayed a similar behavior (Figure 3). The successful addition of phosphonyl radicals onto gem-difluoro enol ether 
derivatives 29-31 by the groups of Motherwell and Sinaÿ may be indicative of the electrophilic nature of the radicals [10c, $10 \mathrm{~h}, \mathbf{1 0 j}]$.

\section{Scheme 7}

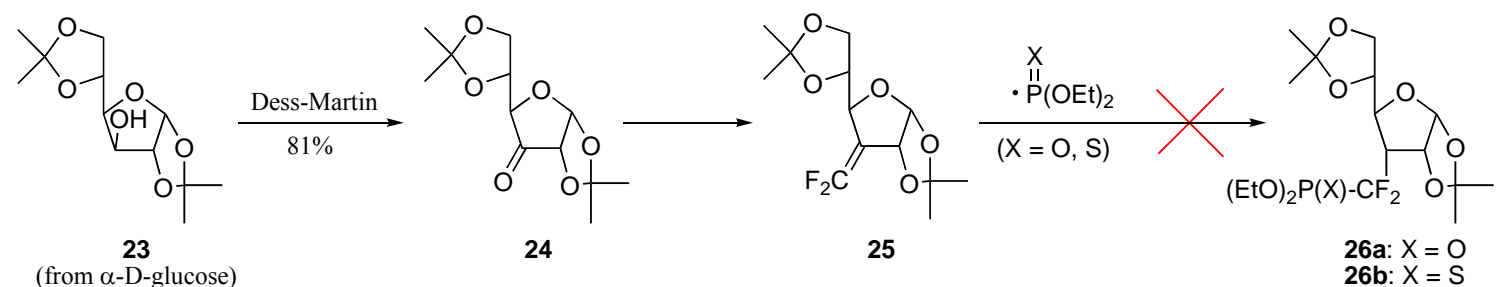

Figure 3

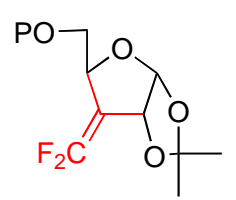

19

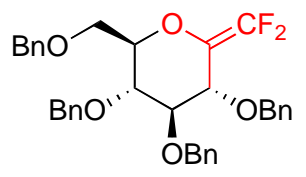

$29(14 \%)$
DPTBS-O
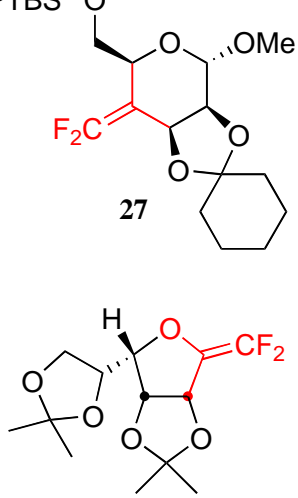

$30(23 \%)$
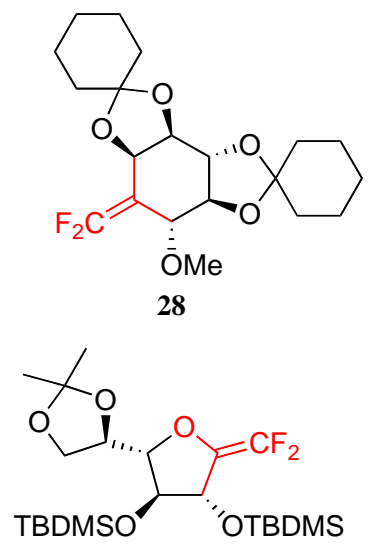

$31(56 \%)$

(Sinä̈, 1999)

A literature search for alternate precursors of phosphorus-centered radicals quickly led to the identification of hypophosphorous acid 32a, featuring two P-H bond and only one phosphorus-oxygen single bond. Indeed, the work of Nifant'ev has demonstrated the possibility of adding hypophosphorous acid onto alkenes 33 under radical-chain reaction conditions, thereby producing $H_{-}$ phosphinates 34 (single addition) or phosphinates 35 (double addition) (Scheme 8) [16].

\section{Scheme 8}
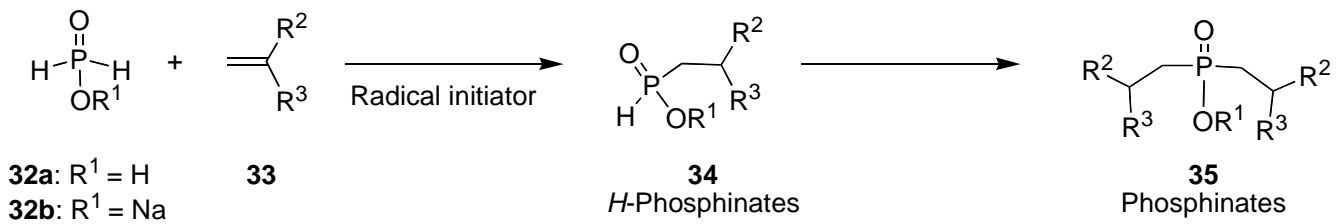

Nifant'ev also showed that the sodium salt 32b of hypophosphorous acid behaves similarly, a feature of importance in the context of acid-sensitive protected substrates. In addition, we were especially interested in testing hypophosphorous acid (or its sodium salt) addition onto gemdifluoroalkenes, as this would open the door to both hitherto unreported $\alpha, \alpha$-difluoro- $H$-phosphinates, and $\alpha, \alpha$-difluorophosphinates, a functional group for which no general method of synthesis has been reported to date. 
Thus, refluxing a solution of either difluoroalkene 36-39 and 32b in methanol in the presence of a catalytic amount of tert-butyl peroxypivalate (40) resulted in a complete consumption of the sustrates. Hydrolysis and work-up led to the isolation of the first $\alpha, \alpha$-difluoro- $H$-phosphinates 42-45 in good yields (Scheme 9). The compounds were found to be both air and room temperature stable for extended periods of time and displayed a one-bond $\mathrm{P}-\mathrm{H}$ coupling constant of about $560 \mathrm{~Hz}\left({ }^{31} \mathrm{P}-\mathrm{NMR}\right.$ spectrometry). Infrared spectra featured both $\mathrm{P}=\mathrm{O}$ and $\mathrm{P}-\mathrm{H}$ bonds signals, indicative of a $\mathrm{P}(\mathrm{V})$ species. Other successful radical initiators included commercially available tert-butyl 2-ethylhexyl peroxycarbonate and the triethylborane/air system [17].

\section{Scheme 9}

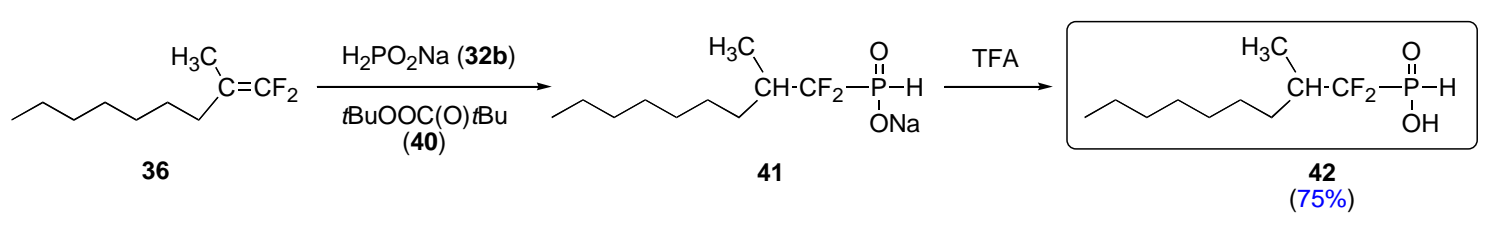

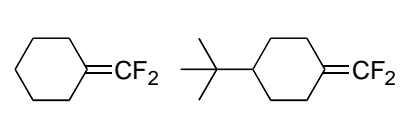

37
38

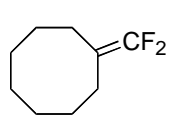

39



43
$(85 \%)$

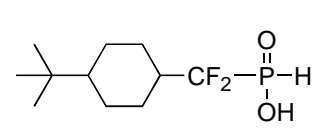

44
$(83 \%)$

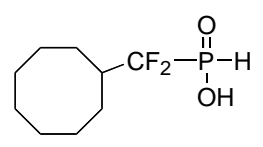

45
$(79 \%)$

Homolytic cleavage of the phosphorus hydrogen single bond present in difluoro- $H$-phosphinates was achieved by heating the compounds in the presence of both an alkene (1 equiv) and a radical initiator. Thus, for instance, $H$-phosphinate 43 sequentially reacted with either alkene 46 or $\mathbf{4 7}$, and diazomethane (CAUTION) to deliver methyl $\alpha, \alpha$-difluorophosphinates $\mathbf{5 0}$ and $\mathbf{5 1}$ in good isolated yield (Scheme 10).

\section{Scheme 10}

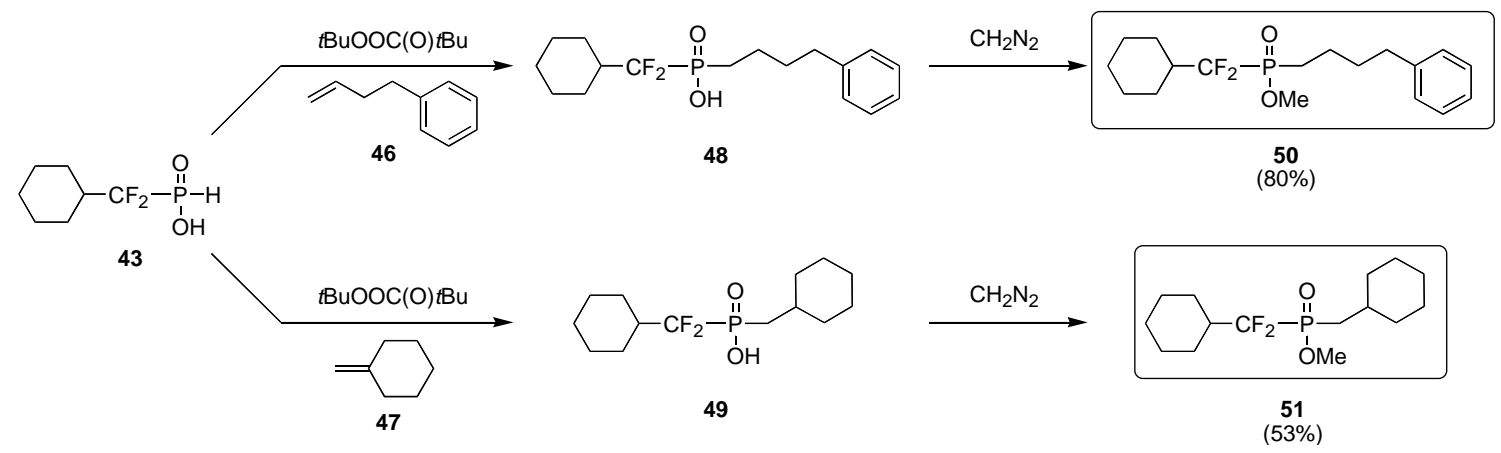

The documented tautomeric equilibrium between $H$-phosphonates 52 and phosphites $\mathbf{5 3}$ led us to develop alternate ionic routes to $\alpha, \alpha$-difluorophosphinates [18]. Treatment of $\alpha, \alpha$-difluoro- $H-$ phosphinates $\mathbf{4 3}$ and $\mathbf{4 4}$ with trimethylsilyl chloride in the presence of pyridine afforded the airsensitive $O, O$-bissilylated phosphites 54 and 57, which were then subjected into interaction with methyl vinyl ketone 55 and pivalaldehyde 58, respectively (Scheme 11). Hydrolysis and esterification with diazomethane (CAUTION) cleanly delivered difluorophosphinates 56 and 59 [19,20]. Of particular note is the fact that the two fluorine atoms present in the $O, O$-bissilylated phosphites did not prevent the phosphorus atom from reacting with electrophilic centers. 


\section{Scheme 11}
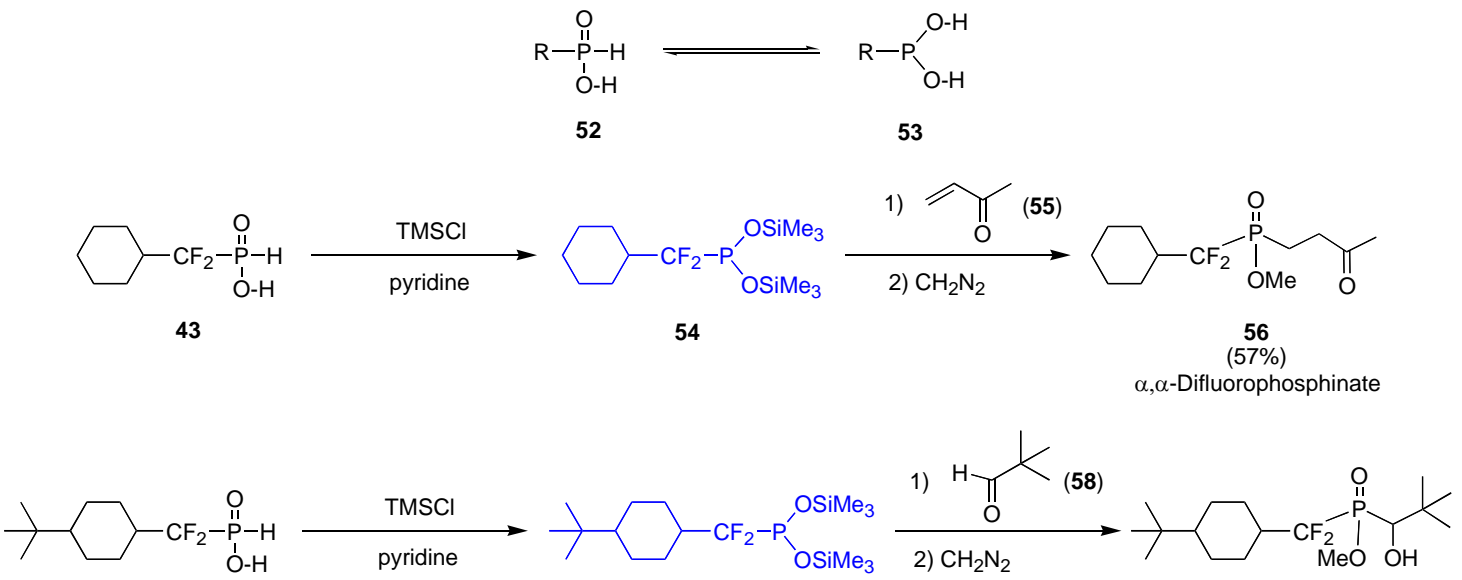

44

57

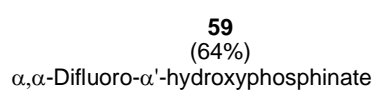

Alternatively, treating these bissilylated phosphites with either oxygen or sulfur led to the isolation of difluorinated phosphonic and phosphonothioic acids, respectively, as exemplified in Scheme 12.

Scheme 12

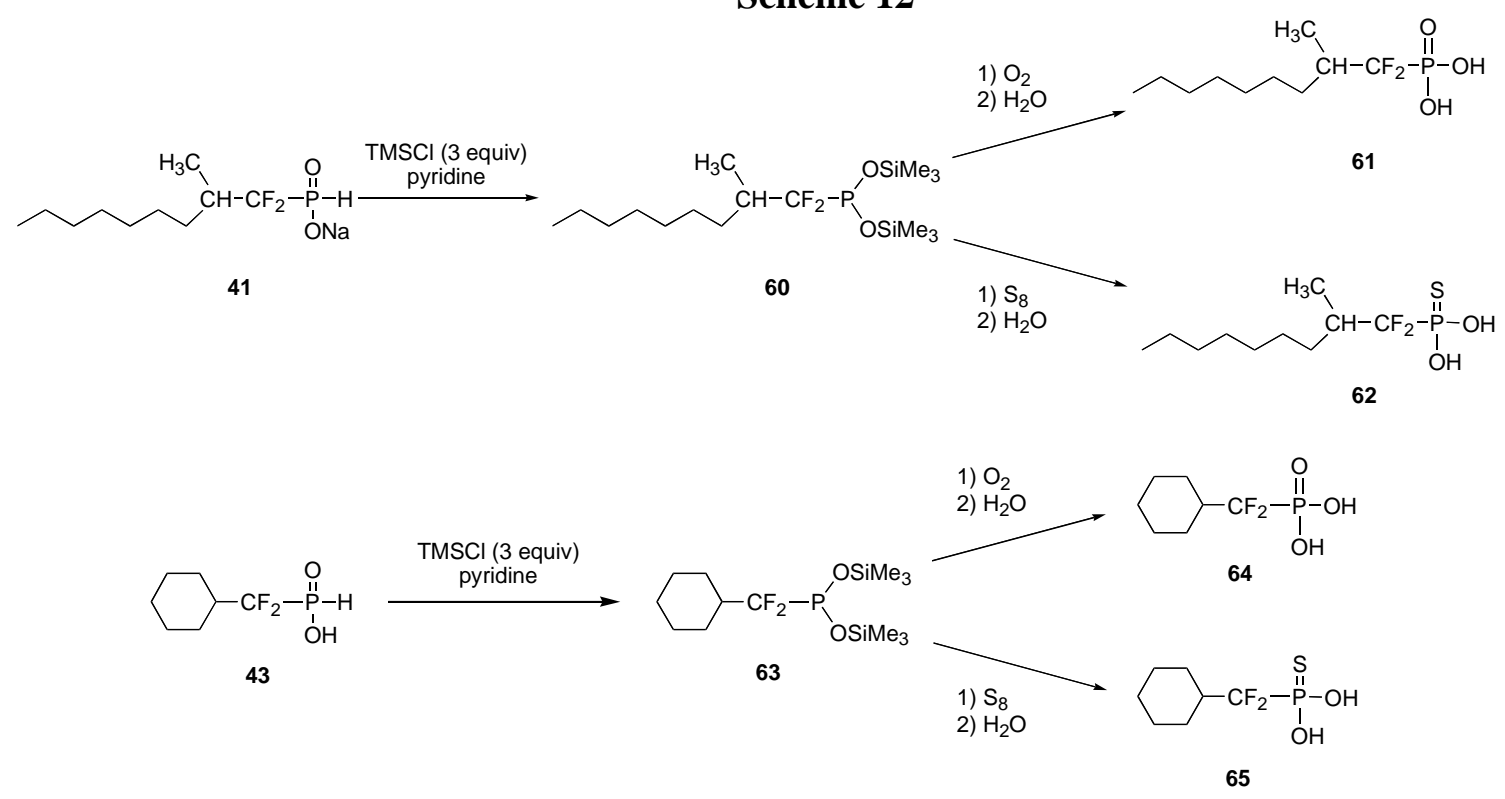

More importantly, when hypophosphorous sodium salt 32b was reacted with difluoroalkene 19a (a substrate inert to the action of both phosphite and thiophosphite) under the above conditions, a clean reaction occurred and adduct $\mathbf{6 7}$ was isolated in $78 \%$ yield as a single diastereomer (Scheme 13). ${ }^{1} \mathrm{H}-$ NMR spectrometry indicated the structure to be as depicted, indicative of the efficiency of the angular methyl group of the 1,2-isopropylidene unit in keeping hydrogen quenching of radical-adduct $\mathbf{6 6}$ from occurring on the concave face [12]. Transformation into $O, O$-bissilylated phosphite $\mathbf{6 8}$ and sequential treatment with oxygen and water delivered the expected phosphonic acid, isolated in the form of its disodium salt 69a in excellent yield. An analogous sequence involving sulfur in place of oxygen afforded the corresponding phosphonothioate $\mathbf{6 9 b}$. 


\section{Scheme 13}



Similarly, difluoroalkene 19b and hypophosphorous acid sodium salt reacted together at room temperature in presence of $\mathrm{Et}_{3} \mathrm{~B}$ and oxygen (air) as the radical initiator to furnish the $\alpha, \alpha$-difluoro$H$-phosphinate, sodium salt 70a, conveniently purified as its triethylammonium salt 70b by ion exchange and simple extraction with ethyl acetate (Scheme 14) [111]. An additional step forward was accomplished when this compound could be esterified with alcohol $\mathbf{7 1}$ in the presence of trifluoroacetic acid and dicyclohexyl carbodiimide (DCC). Treatment of the resultant $H$-phosphinate 72 with a mixture of sulfur, $\mathrm{TMSCl}$ and pyridine gave difluorophosphonothioate $\mathbf{7 3}$, isolated in $50 \%$ yield as a 1:1 diastereomeric mixture at the phosphorus center [17].

\section{Scheme 14}

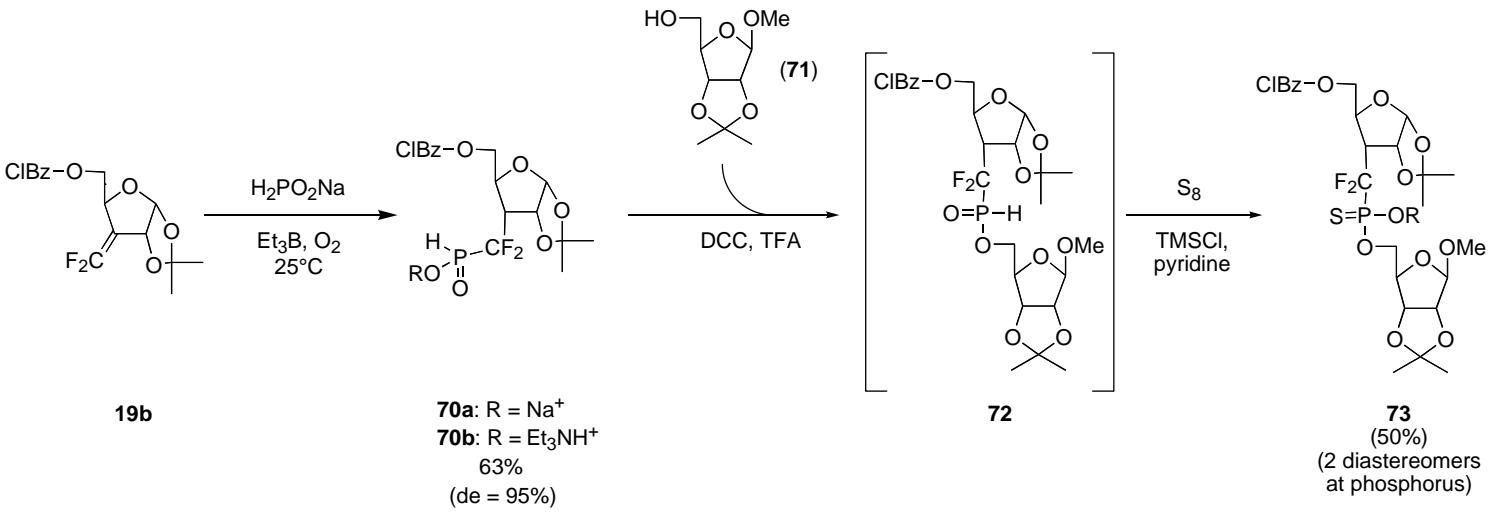

The possibility of using the Nifant'ev protocol to link two furanoses on position 3 and 5 with a dimethylphosphinoyl (i.e. generate compound 75, Scheme 15) was also verified. A double disconnection of the two phosphorus-carbon bonds points the finger at alkenes $\mathbf{7 5}$ and $\mathbf{7 7}$ as protected starting substrates and at a synthetic equivalent of diradical 76. As demonstrated earlier, a process using hypophosphorous acid sodium salt in two sequential radical addition reactions would achieve this. Two possible syntheses exist, depending on which alkene $\mathbf{7 5}$ or $\mathbf{7 7}$ is used first. Here again, a stereocontrol is needed in the hydrogen quench of any radical-adduct generated from alkene 75 . The 
demonstrated efficiency of a 1,2-isopropylidene unit (see above) led us to consider furanose $\mathbf{8 0}$, along with 32b and $\mathbf{8 1}$.

\section{Scheme 15}

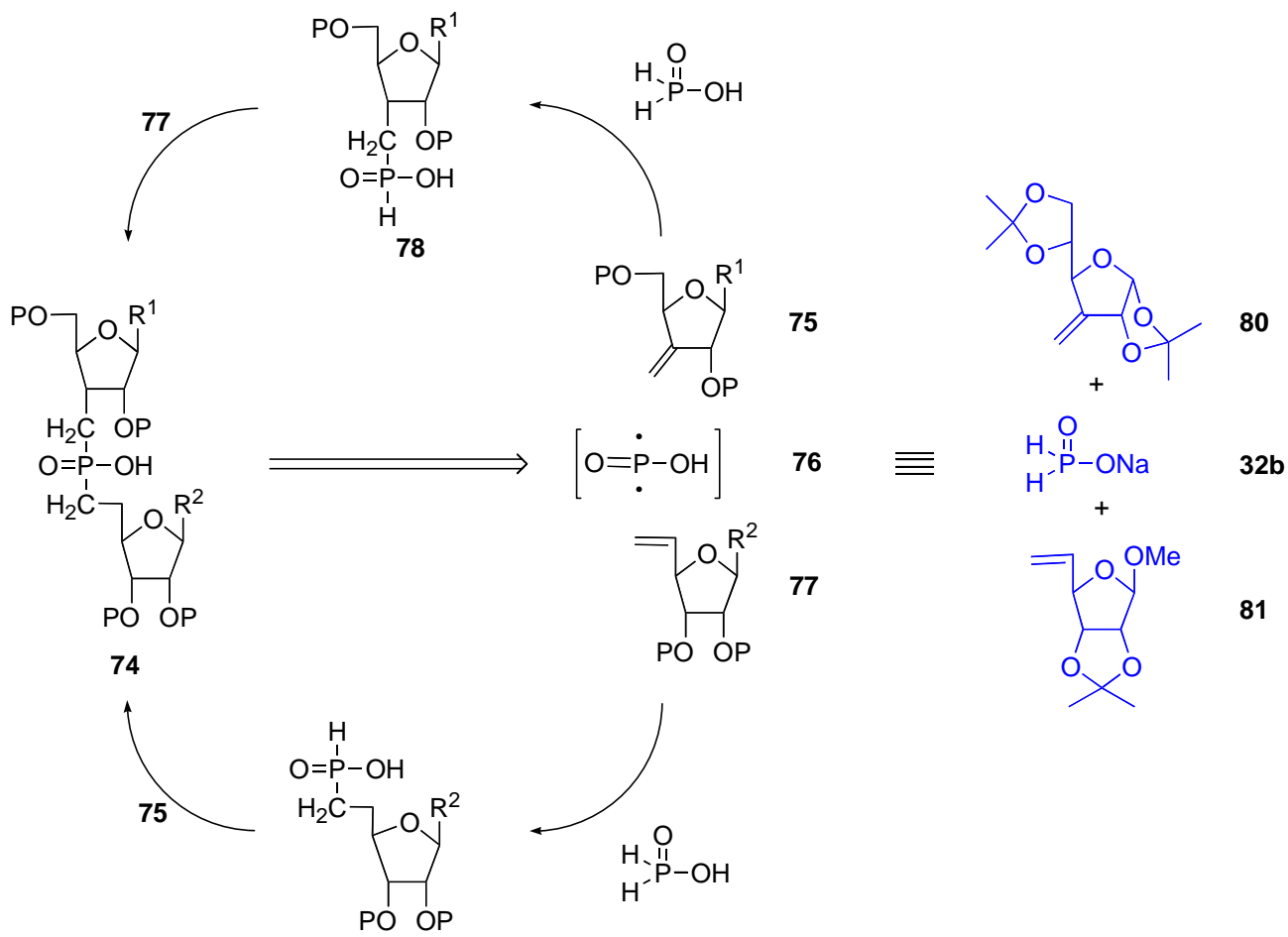

79

Reaction of a solution of alkene $\mathbf{8 0}$ in EtOH with hypophosphorous acid sodium salt 32b (5 equiv) in the presence of di-tert-butyl peroxide at $120^{\circ} \mathrm{C}$ resulted in the quantitative formation of $H$ phosphinate 82a isolated in the form of its methyl ester 82c (diazomethane) as a single disatereomer (Scheme 16). Similarly, alkene $\mathbf{8 1}$ generated the expected adduct 83c in virtually quantitative yield [21].

\section{Scheme 16}

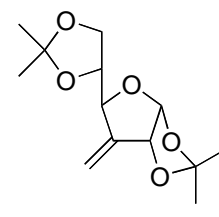

80

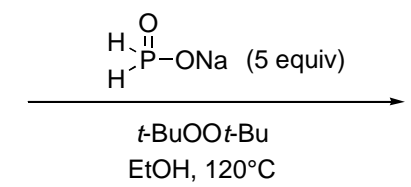

$\mathrm{EtOH}, 120^{\circ} \mathrm{C}$

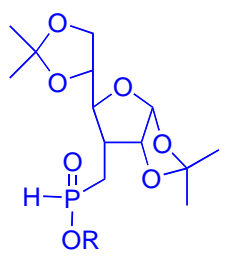

82a: $\mathrm{R}=\mathrm{Na}$

82b: $\mathrm{R}=\mathrm{H}$

82c: $R=M e(97 \%$; de $>95 \%)$

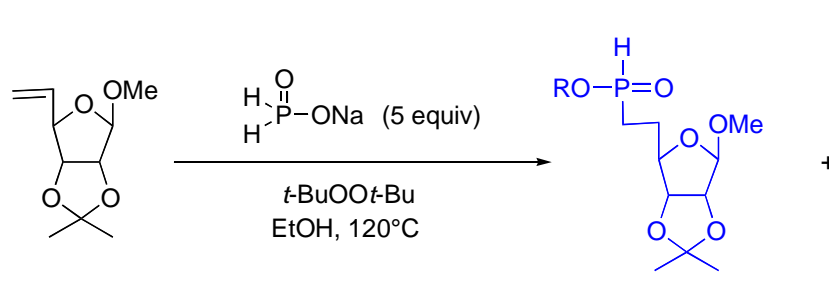


Both $H$-phosphinate 82c and 83c were then subjected to the action of tert-butyl peroxopivalate in the presence of alkene $\mathbf{8 1}$ and $\mathbf{8 0}$, respectively. A 1:3 mixture of the expected methyl phosphinate $\mathbf{8 5}$ and phosphinic acid $\mathbf{8 6}$ were obtained in each case, which was treated with diazomethane (CAUTION) to deliver methyl ester 85 in 82 and 70\% isolated yield (Scheme 17). Phosphinic acid 86 was probably formed through internal hydrogen quenching of the radicals-adducts by the methyl group of phosphinic ester, loss of formaldehyde, hydrogen quenching of the thereby-formed phosphorus radical and oxidation of the resultant $H$-phosphine oxide (through its P(III) tautomer) during work-up. These results thus demonstrated that the Nifant'ev protocol can be efficiently exploited to prepare 3furanosyl-5'-furanosylphosphinate through a tandem sequential radical process.

\section{Scheme 17}

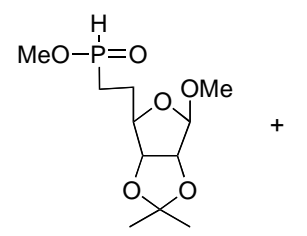

83c

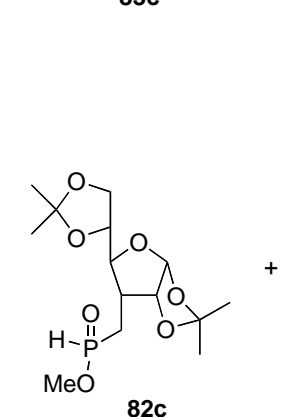

82c

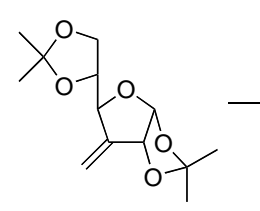

80

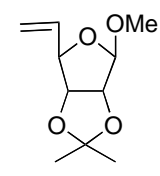

81

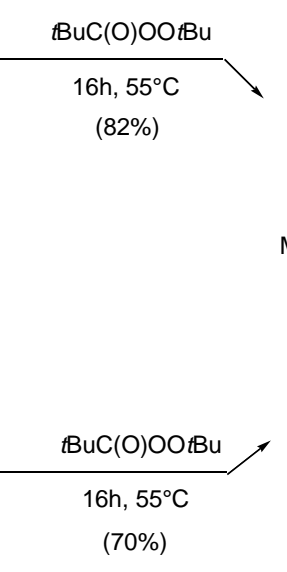

$(70 \%)$

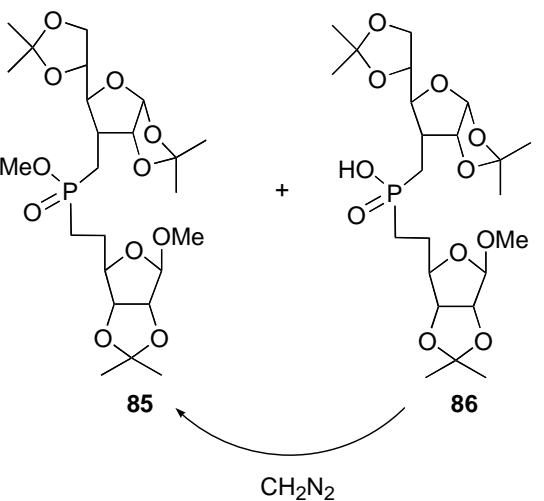

\section{b) Ionic approach}

An alternate approach, relying on the ionic introduction of the phosphonodifluoromethyl unit was also considered. The retrosynthetic analysis of our target molecules 12a is outlined in Scheme 18. Based on Berkowitz' work, a two-step process calling for (i) the addition of reagent 87a onto a keto group and (ii) a radical-based deoxygenation of the resultant adduct was developed [10d]. Here again, the stereodirecting effect of the base was expected to result in a predominant attack of nucleophilic species 87a on the convex face of the molecule to generate 88. However, the same stereodirecting effect acting on the hydrogen quenching of radical intermediate 15a during the deoxygenation step would probably provide the undesired diastereomer 16a. As this last step would probably play a crucial role in installing the requisite configuration on carbon $\mathrm{C}_{3}$, it was decided to start from a furanose derivative featuring a hindered concave face to force the hydrogen quenching to occur on the convex face (thereby positioning the phosphonodifluoromethyl unit on the desired face of the ring), and to introduce the base in a subsequent step, thus paralleling the radical approach (see above). However, interacting either 87a or the analogous organomagnesium reagent 87b [22], with ketone 24 never resulted in a clean transformation, and product $\mathbf{8 9}$ was isolated in yields lower than $20 \%$, along with substantial amounts of bis( $O, O$-diethylphosphono)difluoromethane and the hydrate of the starting ketone (Scheme 19) [15]. 


\section{Scheme 18}

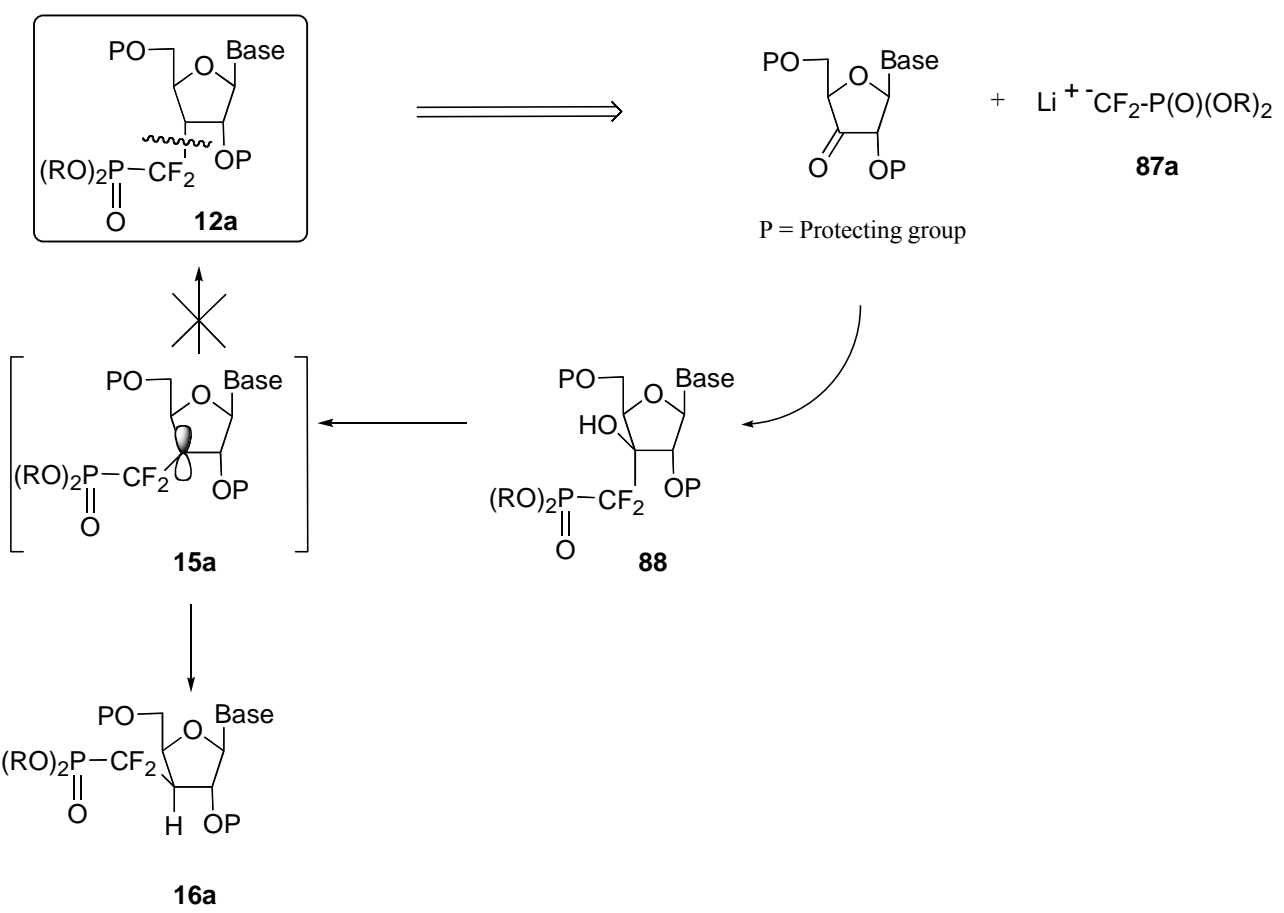

Scheme 19


We next considered the thioanalogues 91a-91c of reagent 87a (Scheme 20, Figure 4). The thermally more stable lithiated reagent 91a is conveniently prepared either by treatment of difluoromethylphosphonothioate 90 with lithium diisopropylamide, or by interacting bromodifluorophosphonothioate 92 and tert-butyllithium [23]. Reagent 91a has been shown to be stable at temperatures up to $-20^{\circ} \mathrm{C}$, thus favorably comparing to phosphonate 87a, stable only at $-78^{\circ} \mathrm{C}$ or below [24].

Scheme 20

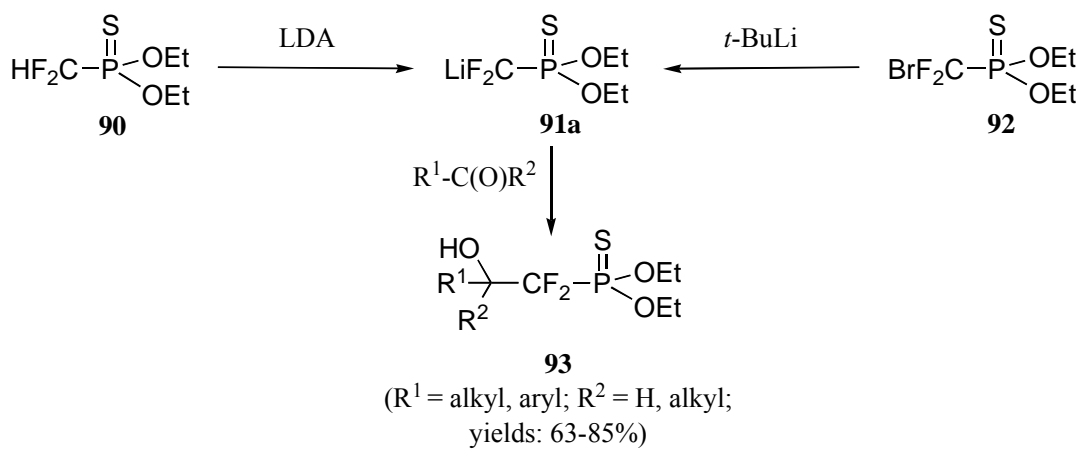


The reactivity of 91a parallels that of 87a, and was found to smoothly react with ketones and aldehydes to deliver the expected adducts 93 in good yields. Lithiated reagents $91 \mathbf{b}$ and 91c were however found to be thermally unstable, even at $-78^{\circ} \mathrm{C}$; compounds encompassing these two last functional groups were therefore prepared through phosphorus group manipulation [25].

\section{Figure 4}

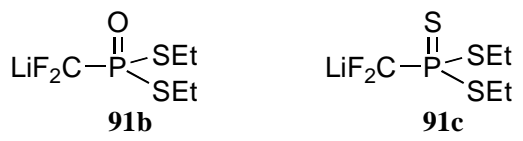

Reacting ketone 24 with 91a resulted in a clean consumption of the starting material and the formation of a single product 94, isolated in 78\% yield (Scheme 21). NMR Spectrometry analysis proved the diastereoselection of the process to be over 99\%. Again, we assumed that the addition of the nucleophile had occurred on the convex face, i.e. opposite to the angular methyl group. Deoxygenation of carbon 3 was achieved by sequential treatment of alcohol 94 with first $n$-butyllithium and $O$-methyl oxalyl chloride, then tri- $n$-butyltin hydride in the presence of azobisisobutyronitrile (catalytic amount). Product 97 was isolated in $79 \%$ yield as a single diastereomer. Analysis of the NMR data confirmed the stereochemical inversion of the phosphonothiodifluoromethyl unit from the convex face to the concave one, the result of hydrogen quenching of the radical adduct 96 exclusively from the convex face. Carbon 6 was then removed from the glucofuranose skeleton by selective deprotection, oxidation and reduction to furnish alcohol $\mathbf{1 0 0}$ which was transformed into triacetate 101 in $13 \%$ overall yield from ketone 24 .

Scheme 21
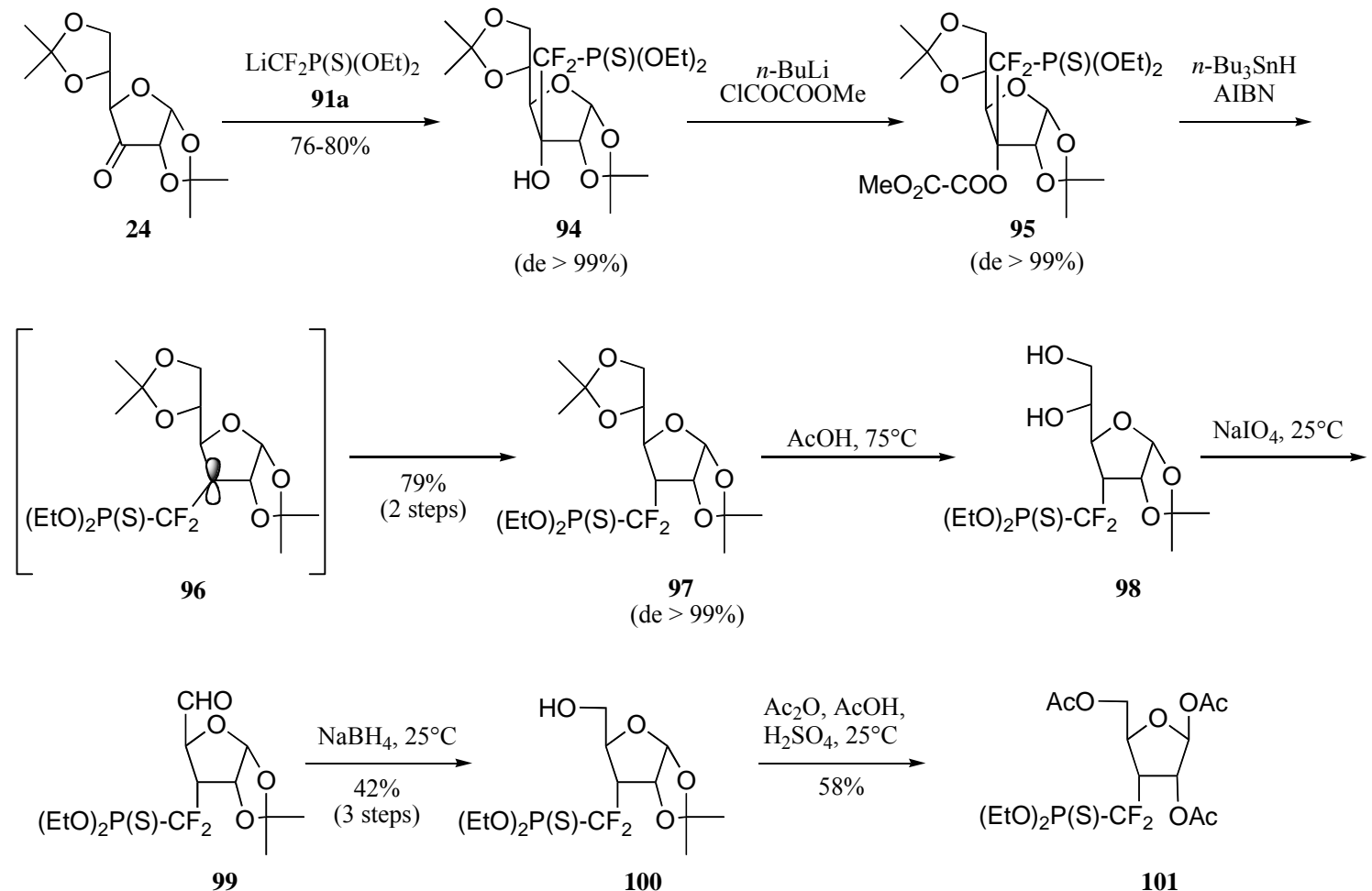
Attempts to improve both the synthesis and the overall yield started with a critical analysis of this route. This led to the identification of several drawbacks impeding its use in larger scale preparation of 101. Thus, LDA or tert-butyllithium were used as base, and chromatography had to be used to obtain several intermediates in the pure form. The involvement of the somewhat hazardous Dess-Martin periodane was also considered as a limitation to the development of a larger scale preparation. Moreover, the 6-carbon starting substrate implied additional steps to obtain the five-carbon skeleton of ribofuranose 101. An improved synthesis was thus worked out, starting from $\alpha-D-x y l o s e ~ d e r i v a t i v e$ 102 (Scheme 22). The required 1,2-isopropylidene protection was completed by the installation of a para-chlorobenzoyl unit on the 5'-hydroxyl group. An additional feature of para-chlorobenzoate derivatives lies in their propensity to crystallize (see below) [26].

\section{Scheme 22}
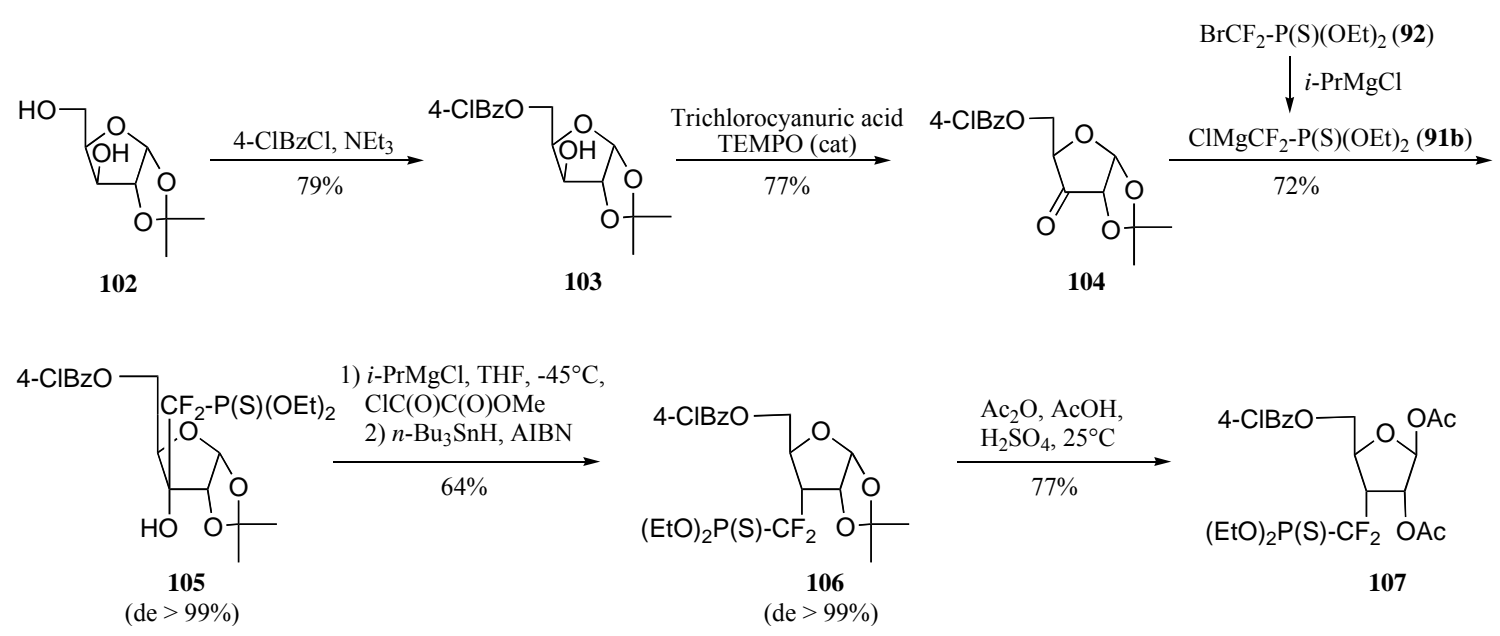

Alcohol 103 was oxidized by a mixture of trichlorocyanuric acid and 2,2,6,6-tetramethylpiperidine $N$-oxide (TEMPO) in catalytic amount to deliver ketone 104 in 77\% isolated yield [27]. Lithium reagent 91a was replaced with the organomagnesium reagent 92b, readily prepared by treating bromide 92 with 1.1 equivalents of freshly prepared iso-propyl magnesium chloride in diethyl ether [22]. For the reason cited above, adduct $\mathbf{1 0 5}$ was obtained as a single diastereomer. Again, radical deoxygenation of this adduct resulted in a clean stereochemical inversion of the phosphonothiodifluoromethyl moiety, and phosphonothioate 106 was obtained in 64\% isolated yield (two steps) as a single diastereomer. Treatment of this product with acetic anhydride in a mixture of acetic acid and sulfuric acid removed the 1,2-acetonide and furnished triester $\mathbf{1 0 7}$ as a single stereoisomer. This scheme resulted in the formation of a slightly different precursor with an improved overall yield of 21\% from xylose derivative 102. Noteworthy is the fact that no chromatography separation is needed, and that the preparation of $\mathbf{1 0 7}$ has been carried out on a 10-gram scale [28].

Stereoselective installment of the pyrimidine bases was achieved by using Vorbruggen's modification of the Hilbert-Johnson protocol while the purine bases were introduced by using the procedures of Saneyoshi and Robins (Table 2) [29,30]. Isolated yields were good to excellent and a complete diastereoselectivity was observed, as a result of the steric hindrance generated by both the 2acetoxy group and the 3-phosphonothiodifluoromethyl unit. It might be suggested that the longer $\mathrm{P}=\mathrm{S}$ bond (1.90 $\AA$ versus $1.53 \AA$ for the $\mathrm{P}=\mathrm{O}$ bond) allows the latter group to participate in the stabilisation 
of the intermediate cation. Such an analogous participation has recently been described with 2,3dideoxy-3-phosphonothiofuranose derivatives [31]. Of particular note is the excellent regiochemical control observed in the induction of the purine bases: a single regioisomer was found to have formed.

Table 2

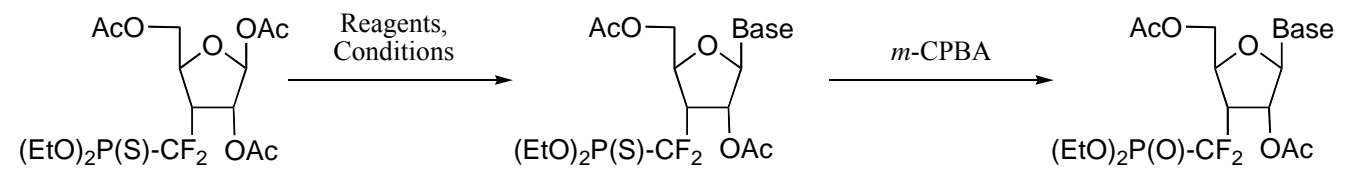

101

108

109

\begin{tabular}{|c|c|c|c|c|c|c|c|}
\hline Entry & Base & Reagent & Conditions & Products & $\begin{array}{c}\text { Yields } \\
(\%)\end{array}$ & Products & $\begin{array}{c}\text { Yields } \\
\text { (\%) }\end{array}$ \\
\hline
\end{tabular}

1<smiles>Cc1cn(CC(C)C)c(=O)[nH]c1=O</smiles>

(T)<smiles>CCOc1nc(OC)ncc1C</smiles>

TMSOTf,

$\mathrm{ClCH}_{2} \mathrm{CH}_{2} \mathrm{C}$

$\begin{array}{lllll}1, & 108 a & 92 & 109 a & 77\end{array}$

$25^{\circ} \mathrm{C}$

2<smiles>CCn1ccc(=O)[nH]c1=O</smiles>

(U)<smiles>COc1ccnc(OC)n1</smiles>

TMSOTf,

$\mathrm{ClCH}_{2} \mathrm{CH}_{2} \mathrm{C}$

$\begin{array}{lllll}1, & \mathbf{1 0 8 b} & 81 & \mathbf{1 0 9 b} & 54\end{array}$

$25^{\circ} \mathrm{C}$

3n<smiles>COc1nccc(NC(C)(C)C)n1</smiles>

TMSOTf,

$\mathrm{ClCH}_{2} \mathrm{CH}_{2} \mathrm{C}$

$80^{\circ} \mathrm{C}$

108c 95

109c

91

(A)<smiles>Nc1ncnc2[nH]cnc12</smiles>

$\mathrm{SnCl}_{4}$,

4
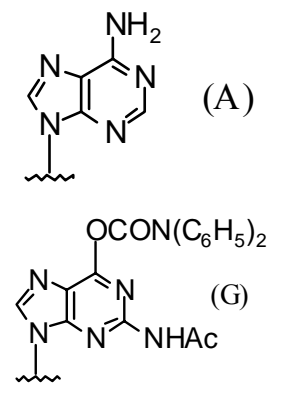<smiles>CCCCCNc1nc(NNC(=O)OCc2ccccc2)c2nc[nH]c2n1</smiles>

$\mathrm{CH}_{3} \mathrm{CN}$, $25^{\circ} \mathrm{C}$

108d

87

109d

73

TMSOTf,

$\mathrm{ClCH}_{2} \mathrm{CH}_{2} \mathrm{C}$

5

1 ,

108e 66

109e

66 $80^{\circ} \mathrm{C}$

Interconversion of difluorophosphonates $\mathbf{5 d}$ and difluorophosphonothioates $\mathbf{5 a}$ can easily be achieved in high yields and require either the action of Lawesson's reagent $\mathbf{1 1 0}(\mathrm{P}=\mathrm{O} \rightarrow \mathrm{P}=\mathrm{S})$ or a mild oxidating agent $(\mathrm{P}=\mathrm{S} \rightarrow \mathrm{P}=\mathrm{O})$ such as dimethyl dioxirane 111, perfluorooxaziridine 112 or $m-\mathrm{CPBA}$ (Scheme 23) [32]. 


\section{Scheme 23}



$77-97 \%$

In this program, nucleotide analogues 108, encompassing the phosphonothiodifluoromethyl unit, were easily transformed into the corresponding phosphonates $\mathbf{1 0 9}$ in good to excellent yields by simple treatment with $m$-CPBA (Table 2). Pyrimidine derivatives 109a-109c were then fully deprotected by reaction with trimethylsilyl bromide, hydrolysis and treatment with methanolic ammonia; the final products 114a-114c were isolated as their disodium salts in yields ranging from 70-77\% (Scheme 24).

Scheme 24


Comparison of both radical and ionic approaches shows them to be equally effective in stereoselectively producing a protected furanose derivative bearing a phosphono(thio)difluoromethyl unit on carbon 3 (Scheme 25).

\section{Scheme 25}

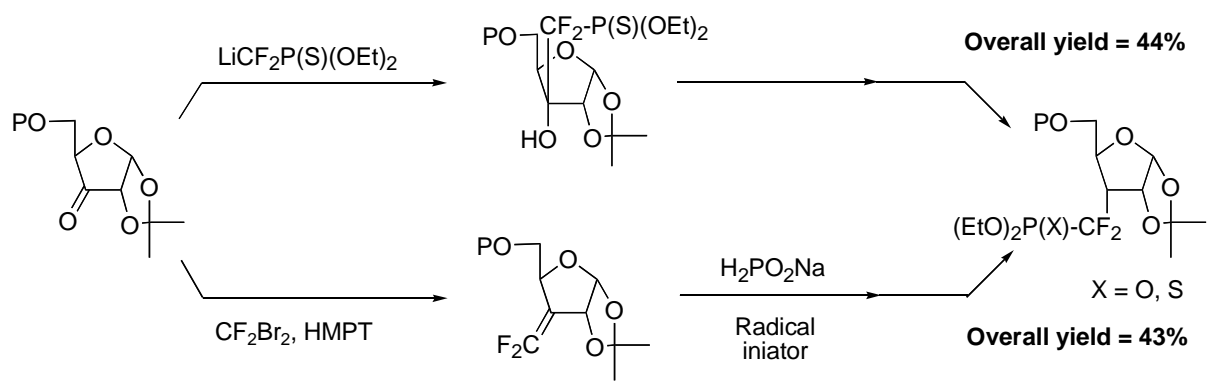




\section{Cyclitols}

\section{Radical approach}

L-Quebrachitol (115) is a waste-product of the natural rubber industry and can be obtained from the serum (aqueous phase) of the latex [33]. Protection of the natural product as biscyclohexylidene acetal derivative $\mathbf{1 1 6}$ and oxidation of the remaining hydroxyl group under the conditions of Swern delivered ketone 117 with five of the six stereocenters present in inositol-3-phosphate. Ketone 117 was next transformed into gem-difluoroalkene 118 by using the three-step procedure published by McCarthy [34]. When a mixture of hypophosphorous acid sodium salt $\mathbf{3 2 b}$ and substrate 118 were heated at $55^{\circ} \mathrm{C}$ in the presence of tert-butyl peroxopivalate as radical initiator, a complete consumption of the substrate was observed and products 119a and 119b were formed (9:1 diastereomeric ratio) (Scheme 26). The neighboring axial ether group was thus efficient in directing the hydrogen quenching to occur on the face opposite to that carbon-oxygen bond. The major product 119a constitutes a key intermediate en route to the phosphono(thio)difluoromethyl analogues of inositol-3-phosphate.

Scheme 26


Quinic acid 120 also represents a useful chiral source for the preparation of modified cyclitols (Scheme 27) [35]. Protection of the three secondary hydroxyl groups was accomplished using literature procedure and the resultant methyl ester 122 was subjected to a decarboxylating oxidation to deliver ketone 123. Transformation into gem-difluoroalkene 124 yielded the substrate on which the radical methodology was applied. The phosphorous-centered radical generated from $\mathbf{3 2} \mathbf{b}$ by the standard procedure once again delivered the expected difluoro- $H$-phosphinates 125 , this time as a 7:3 diastereomeric mixture due to the relative remoteness of the stereodirecting, axial silyl ether group. 


\section{Scheme 27}


Ionic approach

The ionic approach was also tested on a pyranose derivative. Indeed, the possible use of the Ferrier reaction makes of pyranose derivatives a potentially useful entry into the preparation of cyclitol analogues [36]. Thus, $\alpha-\mathrm{D}-$ glucose derivative 126 was protected and oxidized using a three-step sequence of transformations depicted in Scheme 28. The resultant ketone 129 was subjected to the action of lithiated reagent 91a at $-78^{\circ} \mathrm{C}$, and the corresponding alcoholate was quenched with $O$ methyl oxalyl chloride. Difluorophosphonothioate $\mathbf{1 3 0}$ was isolated in $70 \%$ yield as a single diastereomer. Treatment of $\mathbf{1 3 0}$ with tri-n-butyltin hydride and $\mathrm{AIBN}$ in toluene at $100^{\circ} \mathrm{C}$ gave exclusively product 131 in 57\% isolated yield. No stereochemical inversion of the phosphonothiodifluoromethyl group occurred this time, however. Apparently, the steric hindrance generated by the methoxy group forces the radical-adduct to adopt conformation 133 rather than 132, thereby leading to 131 and not 134 (Scheme 29).

\section{Scheme 28}
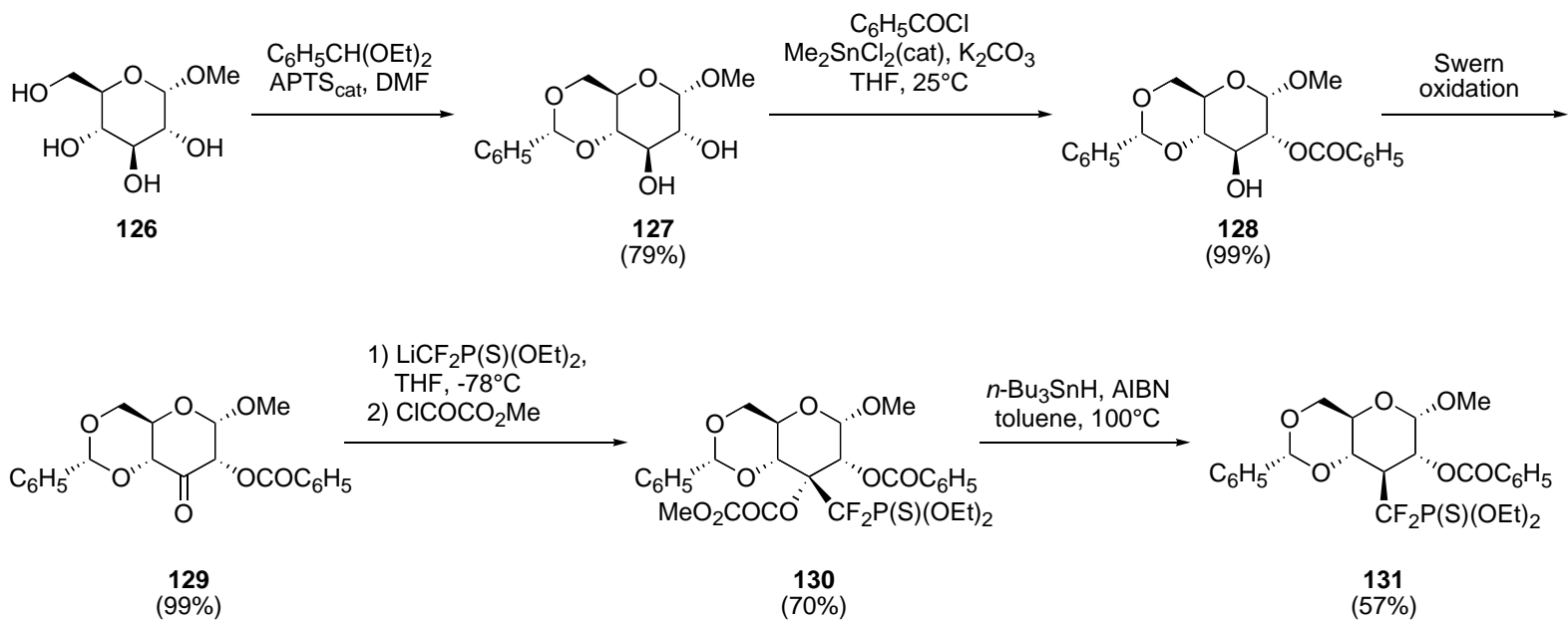
Scheme 29
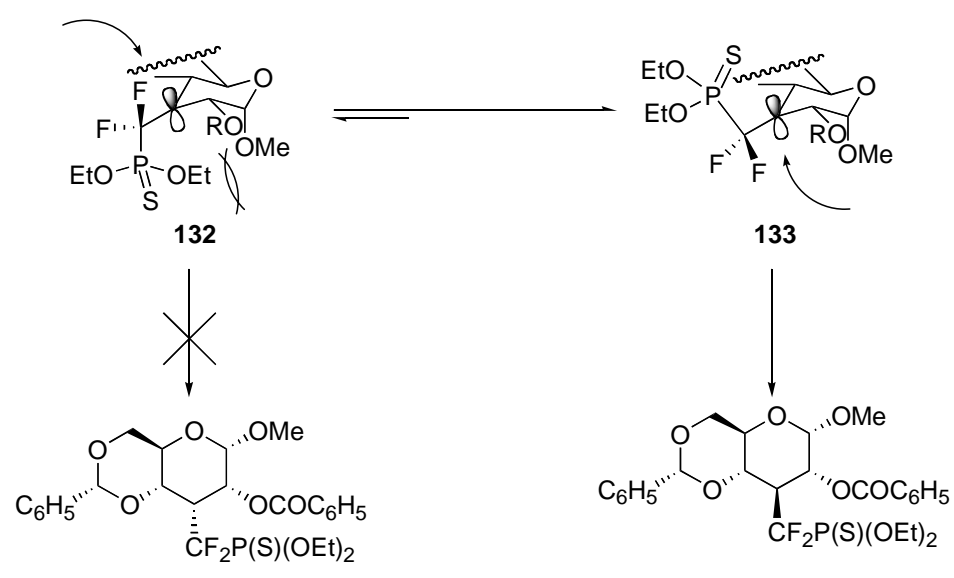

134

131

$X$-ray analyses

Three of the above $\alpha, \alpha$-difluorophosphonothioates $(\mathbf{1 0 5}, \mathbf{1 3 1}$, and the benzyl analogue 135 of 131$)$ were crystalline solids. Careful crystallization led to the growth of monocrystals suitable for X-ray analysis. Figure 5 shows the structures and ORTEP graphics of these three compounds and Table 3 include selected data obtained from the $\mathrm{X}$-ray analyses, along with data published by Chambers and O'Hagan on compounds [3a,3c].

Figure 5

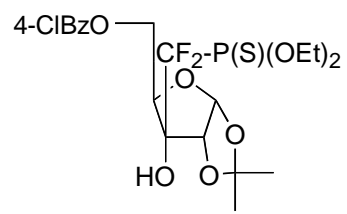

105

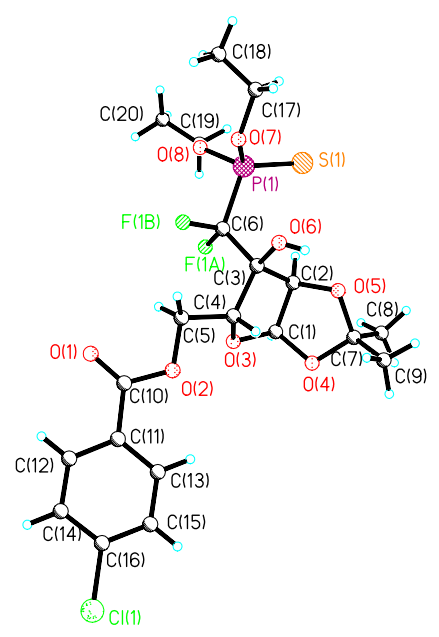

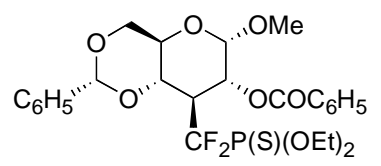

131

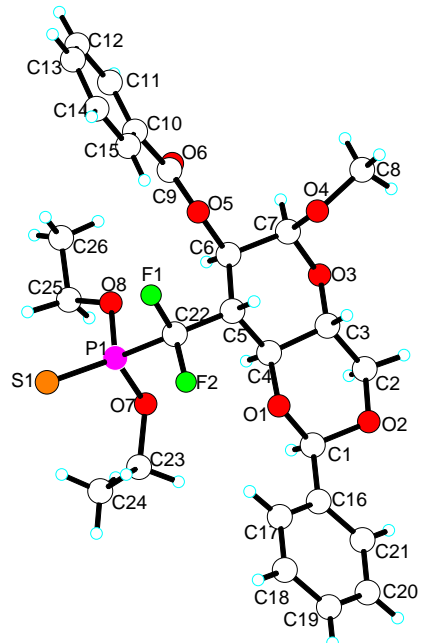

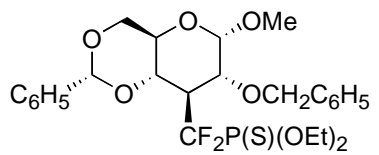

135

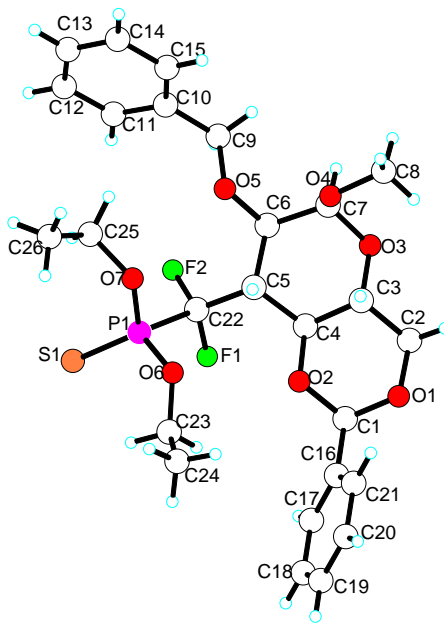


Although the three phosphonothioates are structurally and electronically different than zwitterions 6a and $\mathbf{6 d}$, the data clearly indicate a widening of the angle formed by $\mathrm{C}-\mathrm{CF}_{2}$ and $\mathrm{CF}_{2}-\mathrm{P}$ bonds (Table 3 ). The bond lengths $a$ and $b$ themselves do not vary much from the values reported for difluorophosphonates (e.g. 6d). The length $c$ of the phosphorus-sulfur double bond is, expectedly much larger than the oxygenated counterpart in $\mathbf{6 a}$ and $\mathbf{6 d}$.

Table 3

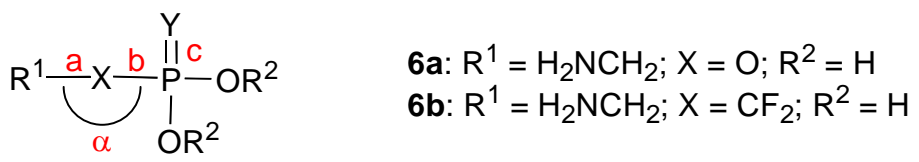

\begin{tabular}{ccccccc}
\hline Compound & $\mathbf{X}$ & $\mathbf{Y}$ & $\boldsymbol{a}(\boldsymbol{\AA})$ & $\boldsymbol{b}(\AA)$ & $\boldsymbol{c}(\AA)$ & $\alpha\left(^{\circ}\right)$ \\
\hline $\mathbf{1 0 5}$ & $\mathrm{CF}_{2}$ & $\mathrm{~S}$ & 1.88 & 1.51 & 1.90 & 120.3 \\
$\mathbf{1 3 1}$ & $\mathrm{CF}_{2}$ & $\mathrm{~S}$ & 1.86 & 1.52 & 1.91 & 122.5 \\
$\mathbf{1 3 5}$ & $\mathrm{CF}_{2}$ & $\mathrm{~S}$ & 1.86 & 1.55 & 1.91 & 117.5 \\
$\mathbf{6 a}$ & $\mathrm{O}$ & $\mathrm{O}$ & 1.59 & 1.43 & 1.52 & 118.5 \\
$\mathbf{6 d}$ & $\mathrm{CF}_{2}$ & $\mathrm{O}$ & 1.85 & 1.50 & 1.53 & 116.5 \\
\hline
\end{tabular}

\section{Conclusions}

Our journey into the field of new phosphate isosters related to the difluorophosphonates has allowed the preparation of new functional entities such as the difluorinated phosphonothioates, phosphonodithioates and phosphonotrithioates, in which the sulfur atom(s) may either play a positive role in the course of a reaction, or have a deleterious effect on the outcome of a desired transformation. Thus the presence of the double-bonded sulfur atom in reagents $\mathbf{9 1}$ induced a dramatic, positive effect in the condensation on ketone 19, 24 and 129, which ultimately translated into a stereocontrolled synthesis of the phosphonodifluoromethyl analogues of nucleoside-3'-phosphates. Despite the positive effect of sulfur on the addition of phosphonothioyl radical - when compared to the fully oxygenated analogues -, it was simply not enough to induce an addition reaction on functionalized, cyclic gemdifluoroalkenes (e.g. 19, 27 or 28). Hypophosphorous acid sodium salt 32b brings a solution to this problem and displays a reactivity that allows the easy preparation of a variety of phosphate isosters through the intermediary of $\alpha, \alpha$-difluoro- $H$-phosphinates. It also allows to stereoselectively link two furanose units on carbon 3 and $5^{\prime}$ ' with a phosphinyl or a difluorophosphonothioyl unit, and to produce new fully protected analogues of inositol phosphates. Work is in progress in this laboratory to fully explore the possibilities offered by this chemistry.

\section{Acknowledgements}

We are grateful to Prof Alexandre Boutorine for helpful discussions. C. S. thanks the European Union for a grant (Erasmus Program). 


\section{References and Notes}

[1] Hartley, F. R., Ed. The Chemistry of Organophosphorus Compounds, Vol 4, Ter- and Quinquevalent Phosphorus Acids and Their Derivatives; John Wiley \& Sons: Chichester, 1996.

[2] (a) Blackburn, G. M.; England, D. A.; Kolmann, F. J. Chem. Soc., Chem. Commun. 1981, 930932; (b) Blackburn, G. M.; Kent, D. E.; Kolkmann, F. J. Chem. Soc., Chem. Commun. 1981, 1188-1190; (c) McKenna, C. E.; Shen, P.-D. J. Org. Chem. 1981, 46, 4573-4576. (d) Blackburn, G. M.; Kent, D. E. J. Chem. Soc., Perkin Trans 1 1986, 913-917; (e) Phillion, D. P.; Cleary, D. G. J. Org. Chem. 1992, 57, 2763-2764 ; (f) Burke Jr, T. R.; Kole, H. K.; Roller, P. P. Biochem. Biophys. Res. Commun. 1994, 204, 129-134 ; (g) Halazy, S.; Ehrhard, A.; Eggenspiller, A.; Berges-Gross, V.; Danzin, C. Tetrahedron 1996, 52, 177-184 ; (h) Higashimoto, Y.; Saito, S.; Tong, X.-H.; Hong, A.; Sakaguchi, K.; Appella, E.; Anderson, C. W. J. Biol. Chem. 2000, 275, 23199-23203.

[3] (a) Chambers, R. D.; O’Hagan, D.; Lamont, R. B.; Jain, S. C. Chem. Commun. 1990, 1053-1054;

(b) Thatcher, G. R. J.; Campbell, A. S. J. Org. Chem. 1993, 58, 2272-2281 ; (c) Nieschalk, J. N.; Batsanov, A. S.; O’Hagan, D.; Chambers, R. D. Tetrahedron 1996, 52, 165-176.

[4] (a) Burke Jr., T. R.; Smyth, M. S.; Nomizu, M.; Otaka, A.; Roller, P. P. J. Org. Chem. 1993, 58, 1336-1340 ; (b) Martin, S. F.; Wong, Y.-L.; Wagman, A. S. J. Org. Chem. 1994, 59, 4821-4831; (c) Berkowitz, D. B.; Shen, Q.; Maeng, J.-H. Tetrahedron Lett. 1994, 35, 6445-6448 ; (d) Burke Jr., T. R.; Ye, B.; Akamatsu, M.; Ford Jr., H.; Yan, X.; Kole, H. K.; Wolf, G.; Shoelson, S. E.; Roller, P. P. J. Med. Chem. 1996, 39, 1021-1027 ; (e) Berkowitz, D. B.; Eggen, M.; Shen, Q.; Shoemaker, R. K. J. Org. Chem. 1996, 61, 4666-4675; (f) Ye, B.; Burke Jr., T. R.; Tetrahedron 1996, 52, 9963-9970; (g) Qabar, M. N.; Urban, J.; Khan, M. Tetrahedron 1997, 53, 1117111178; (h) Yokomatsu, T.; Abe, H.; Yamagishi, T.; Suemune, K.; Shibuya, S. J. Org. Chem. 1999, 64, 8413-8418; (i) Burke Jr., T. R.; Lee, K. Acc. Chem. Res. 2003, 36, 426-433.

[5] (a) Blackburn, G. M.; Kent, D. E. J. Chem. Soc., Chem. Commun. 1981, 511-513; (b) Blackburn, G. M.; Kent, D. E.; Kolkmann, F. J. Chem. Soc., Perkin Trans. 1 1984, 1119-1125; (c) Blackburn, G. M.; Guo, M.-J.; Langston, S. P.; Taylor, G. E. Tetrahedron Lett. 1990, 31, 56375640; (d) Blackburn, G. M.; S. P. Langston, S. P. Tetrahedron Lett. 1991, 32, 6425-6428; (e) Matulic-Adamic, J.; Usman, N. Tetrahedron Lett. 1994, 35, 3227-3230; (f) Matulic-Adamic, J.; Haeberli, P.; Usman, N. J. Org. Chem. 1995, 60, 2563-2569; (g) Levvy, S. G.; Wasson, B.; Carson, D. A.; Cottam, H. B. Synthesis 1996, 843-846; (h) Hamilton, C. J.; Roberts, S. M.; Shipitsin, A. J. Chem. Soc., Chem. Comm. 1998, 1087-1088; (i) Hamilton, C. J.; Roberts, S. M. J. Chem. Soc., Perkin Trans. 1 1999, 1051-1056.

[6] (a) Collingwood, S. P.; Baxter, A. D. Synlett 1995, 703; (b) Regan, A. C.; Sciammetta, N.; Tattersall, P. I. Tetrahedron Lett. 2000, 41, 8211-8215; (c) Centrone, C. A.; Lowary, T. L. J. Org. Chem. 2003, 68, 8115-8119.

[7] For leading references on antisense and antigene strategies, see: (a) De Mesmaeker, A.; Häner, R.; Martin, P.; Moser, H. E. Acc. Chem. Res. 1995, 28, 366-374; (b) Roush, W. Science 1997, 276, 1192-1193; (c) Gee, J. E.; Robbins, I.; van der Laan, A. C.; van Boom, J. H.; Colombier, C.; Leng, M.; Paible, A. M.; Nelson, J. S.; Lebleu, B. Antisense Nucleic Acid Drug Dev. 1998, 8, 103-111; (d) Crooke, S. T. Biochim. Biophys. Acta 1999, 1489, 31-44; (e) Marcusson, E. G.; 
Yacyshyn, B. R.; Shanahan, W. R., Jr.; Dean, N. M. Mol Biotechnol. 1999, 12, 1-11; (f) Taylor, J. K.; Dean, N. M. Curr. Opin. Drug Dev. 1999, 2, 147-151; (g) Holmlund, J. T.; Monia, B. P.; Kwoh, T. J.; Dorr, F. A. Curr. Opin. Mol. Ther. 1999, 1, 372-385; (d) Dorr, F. A. Antisense Nucleic Acid Drug Dev. 1999, 9, 391-396; (h) Lebedeva, I. V.; Stein, C. A. BioDrugs 2000, 13, 195-216.

[8] For a leading reference on the inositol cycle, see: Billington, D. C. "The Inositol Phosphates. Chemical Synthesis and Biological Significance." VCH Publishers : Weinheim, 1991, pp 9-21.

[9] (a) McAllister, G.; Whitting, P.; Hammond, E. A.; Knowles, M. R.; Atack, J. R.; Bailey, F. J.; Maigetter, R.; Ragan, C. I. Biochem. J. 1992, 284, 749-754; (b) Bone, R.; Springer, J. P.; Atack, J. R. Proc. Natl. Acad. Sci. USA 1992, 89, 1031-1035; (c) Bone, R.; Frank, L.; Springer, J. P.; Pollack, S. J.; Osborn S.; Atack, J. R. ; Knowles, M. R.; McAllister, G.; Ragan, C. I.; Broughton, H. B.; Baker, R.; Fletcher, S. Biochemistry 1994, 33, 9460-9467;(d) Bone, R.; Frank, L.; Springer, J. P.; Atack, J. R. Biochemistry 1994, 33, 9468-9476.

[10] (a) Lequeux, T. P.; Percy, J. M. Synlett 1995, 361-362; (b) Piettre, S. R. Tetrahedron Lett. 1996, 37, 2233-2236; (c) Herpin, T. F.; Houlton, J. S.; Motherwell, W. B.; Roberts, B. P.; Weibel, J.M. J. Chem. Soc., Chem. Comm. 1996, 613-614; (d) Berkowitz, D. B.; Eggen, M.; Shen, Q.; Shoemaker, R. K. J. Org. Chem. 1996, 61, 4666-4675; (e) Blades, K.; Lequeux, T. P.; Percy, J. M. Chem. Commun. 1996, 1457-1458; (f) Blades, K.; Cockerill, G. S.; Easterfield, H. J.; Lequeux, T. P.; Percy, J. M. Chem. Commun. 1996, 1615-1616; (g) Blades, K.; Lapôtre, D.; Percy, J. M. Tetrahedron Lett. 1997, 38, 5895-5898; (h) Herpin, T. F.; Motherwell, W. B.; Roberts, B. P.; Roland, S.; Weibel, J.-M. Tetrahedron 1997, 53, 15085-15100; (i) Blades, K.; Percy, J. M. Tetrahedron Lett. 1998, 39, 9085-9088; (j) Kovensky, J.; McNeil, M.; Sinaÿ, P. J. Org. Chem. 1999, 64, 6202-6205; (k) Butt, A. H.; Percy, J. M.; Spencer, N. S. Chem. Commun. 2000, 1691-1692; (1) Yokomatsu, T.; Katayama, S.; Shibuya, S. Chem. Commun. 2001, 18781879; (m) Yokomatsu, T.; Suemune, K.; Murano, T.; Shibuya, S. Heterocycles 2002, 56, $273-$ 282; (n) Butt, A. H.; Kariuki, B. M; Percy, J. M.; Spencer, N. S. Chem. Commun. 2002, 682-683; (o) Murano, T.; Muroyama, S.; Yokomatsu, T.; Shibuya, S. Synlett 2002, 1657-1660; (p) Yokomatsu, T.; Kato, J.; Sakuma, C.; Shibuya, S. Synlett 2003, 1407-1410; (q) Murano, T.; Yuasa, Y.; Muroyama, S.; Yokomatsu, T.; Shibuya, S. Tetrahedron 2003, 59, 9059-9073; (r) Murano, T.; Yuasa, Y.; Kobayakawa, H.; Yokomatsu, T.; Shibuya, S. Tetrahedron 2003, 59, 10223-10230.

[11] (a) Rees, R. D.; James, K.; Tatchell, A. R.; Williams, R. H. J. Chem. Soc. (C) 1968, 276-2721; (b) Sowa, W. Can. J. Chem. 1968, 46, 1586-1589; (c) Bourgeois, J. M. Helv. Chim. Acta 1975, 53, 363-372; (d) Yoshimura, J. Adv. Carbohydr. Chem. Biochem. 1984, 42, 69-134; (e) Giese, B.; Gonzàlez-Gomez, J. A.; Witzel, T. Angew. Chem. Chem. Int. Ed. 1984, 23, 69-70; (f) Giese, B. Angew. Chem. Chem. Int. Ed. 1989, 28, 969-980; (g) Schmit, C. Synlett 1994, 241-242; (h) Johnson, C. R.; Bhumralkar, D. R.; De Clercq, E. Nucleosides \& Nucleotides 1995, 14, 185-194; (i) Lavaire, S.; Plantier-Royon, R.; Portella, C. J. Carbohydr. Chem. 1996, 15, 361-370; (j) Lavaire, S.; Plantier-Royon, R.; Portella, C. Tetrahedron: Asymmetry 1998, 9, 213-226; (k) Lopin, C.; Gautier, A.; Gouhier, G.; Piettre, S. R. Tetrahedron Lett. 2000, 41, 10195-10200; (1) Gautier, A.; Garipova, G.; Dubert, O.; Oulyadi, H.; Piettre, S. R. Tetrahedron Lett. 2001, 42, 5673-5676. 
[12] Lopin, C.; Gouhier, G.; Gautier, A.; Piettre, S. R. J. Org. Chem. 2003, 68, 9916-9923 and references cited therein.

[13] (a) Dess, D. B.; Martin, J. C. J. Am. Chem. Soc. 1991, 113, 7277-7274; (b) Boeckman, R. K.; Shao, P.; Mullins, J. J. Org. Synth. 2000, 77, 141-152.

[14] Serafinowski, P. J.; Barnes, C. L. Synthesis 1997, 225-228.

[15] Lopin, C.; Gautier, A.; Gouhier, G.; Piettre, S. R. J. Am. Chem. Soc. 2002, 124, 14668-14675.

[16] (a) Nifant'ev, E. E.; Koroteev, M.P. Zh. Obshch. Khim. 1967, 37, 1366-1371; (b) Nifant'ev, E. E.; Magdeeva, R. K.; Shchepet'eva, N. P. Zh. Obshch. Khim. 1980, 50, 1416-1422; (c) Nifant'ev, E. E.; Solovetskaya, L. A.; Maslennikova, V. I.; Magdeeva, R. K.; Sergeev, N. M. Zh. Obshch. Khim. 1986, 56, 680-688; (d) Deprele, S.; Montchamps, J.-L. J. Org. Chem. 2001, 66, 67456755.

[17] Gautier, A.; Garipova, G.; Salcedo, C.; Balieu, S.; Piettre, S. R. Angew. Chem. Int. Ed. 2004, 43. In Press.

[18] (a) Stawinski, J.; Kraszewski, A. Acc. Chem. Res. 2002, 35, 952-960; (b) Carruthers, M. H. Acc. Chem. Res. 1991, 24, 278-284; (c) Stawinski, J. "Some Aspects of H-Phosphonate Chemistry"; In Handbook of Organophosphorus Chemistry; Engel, R., Ed.; Marcel Dekker: New York, 1992; pp. 377-434.

[19] For examples of the Pudovik reaction, see: (a) Pudovik, A. N.; Konovalova, I. V. Zh. Obshch. Khim. 1959, 29, 3342-3346; (b) Pudovik, A. N.; Konovalova, I. V. Zh. Obshch. Khim. 1960, 30, 2348-2352; (c) Pudovik, A. N.; Kusovleva, R. G. Zh. Obshch. Khim. 1965, 35, 354-358; (d) Pudovik, A. N.; Batyeva, E. S. Zh. Obshch. Khim. 1969, 334-337; (e) Semenzin, D.; EtemadMoghadam, G.; Albouy, D.; Diallo, O.; Koenig, M. J. Org. Chem. 1997, 62, 2414-2422.

[20] For examples of the Abramov reaction, see: (a) Abramov, V. S. Dokl. Akad. Nauk S.S.S.R 1950, 73, 487-489; (b) Abramov, V. S.; Semenova L. P; Semenova, L. G. Dokl. Akad. Nauk S.S.S.R., 1952; 84, 281-284; (c) Abramov V. S.; Nazmutdinova, A. S. Zh. Obshch. Khim. 1955, 25, 1141 1146; (d) Thiem, J.; Gunther, M.; Paulsen, H.; Kopf, J. Chem. Ber. 1977, 110, 3190-3200; (e) Wroblewski, A. E. Tetrahedron 1986, 42, 3595-3606; (f) Molin, H.; Noren, J. O.; Claesson, A. Carbohydr. Res 1989, 194, 209-221; (g) Engel, R. Handbook of Organophosphorus Chemistry; Marcel Dekker: New York, 1992; (h) Darrow, J. W.; Drueckhammer, D. G. J. Org. Chem. 1994, 59, 2976-2985; (i) Hanessian, S.; Galeotti, N.; Rosen, P.; Oliva, G.; Babu, S. Bioorg. Med. Chem. Lett. 1994, 4, 2763-2768; (j) Darrow, J. W.; Drueckhammer, D. G. Bioorg. Med. Chem. 1996, 4, 1341-1348; (k) Harvey, T. C.; Simiand, C.; Weiler, L.; Withers, S. G. J. Org. Chem. 1997, 62, 6722-6725; (1) Hanessian, S.; Rogel, O. Bioorg. Med. Chem. Lett. 1999, 9, 2441-2446; (m) Hanessian, S.; Rogel, O. J. Org. Chem. 2000, 65, 2667-2674.

[21] Dubert, O.; Gautier, A.; Condamine, E.; Piettre, S. R. Org. Lett. 2002, 4, 359-362.

[22] Waschbüsch, R.; Samadi, M.; Savignac, P. J. Organomet. Chem. 1997, 529, 267-278.

[23] Piettre, S. R.; Raboisson, P. Tetrahedron Lett. 1996, 37, 2229-2232.

[24] Obayashi, M.; Ito, E.; Kondo, K. Tetrahedron Lett. 1982, 23, 2323-2326.

[25] Lopin, C.; Gouhier, G.; Piettre, S. Tetrahedron Lett. 2003, 44. 8837-8840.

[26] Nomura, M.; Sato, T.; Washinosu, M.; Tanaka, M.; Asao, T.;Shuto, S.; Matsuda, A. Tetrahedron 2002, 58, 1279-1288.

[27] DeLucca, L.; Giacomelli, G.; Porcheddu, A. Org. Lett. 2001, 3, 3041-3043. 
[28] Kalinina, I.; Gautier, A.; Salcedo, C.; Valnot, J.-Y.; Piettre, S. R. Tetrahedron 2004, 60. 48954900.

[29] (a) Niedballa, U.; Vorbrüggen, H. Angew. Chem. Int. Ed. 1970, 9, 461-462; (b) Niedballa, U.; Vorbrüggen, H. J. Org. Chem. 1974, 39, 3654-3660; (c) ibid, 3660-3663; (d) ibid, 3664-3667; (e) ibid, 3668-3671; (f) ibid, 3672-3674; (g) Niedballa, U.; Vorbrüggen, H. J. Org. Chem. 1976, 41, 2084-2086; (h) Vorbrüggen, H.; Bennua, B. Tetrahedron Lett. 1978, 39, 1339-1342; (i) Vorbrüggen, H.; Krolikiewicz, K.; Bennua, B. Chem. Ber. 1981, 114, 1234-1255; (j) Vorbrüggen, H.; Hölfe, G. Chem. Ber. 1981, 114, 1256-1268.

[30] (a) Saneyoshi, M.; Satoh, E. Chem. Pharm. Bull. 1978, 27, 2518; (b) Zou, R.; Robins, M. J. Can. J. Chem. 1987, 65, 1436-1437; (c) Robins, M. J.; Zou, R.; Guo, Z.; Wnuk, S. F. J. Org. Chem. 1996, 61, 9207-9212.

[31] Yokomatsu, T.; Sada, T.; Shimizu, T.; Shibuya, S. Tetrahedron Lett. 1998, 39, 6299-6302.

[32] Piettre, S. R. Tetrahedron Lett. 1996, 37, 4707-4710.

[33] Kiddle, J. J. Chem. Rev. 1995, 95, 2189-2202.

[34] Sabol, J. S.; McCarthy, J. R. Tetrahedron Lett. 1992, 33, 3101-3104.

[35] Marco-Contelles, J.; Molina, M. T.; Anjum, S. Chem. Rev. 2004, 104, 2857-2899.

[36] (a) Ferrier, R. J. Chem. Soc., Perkin Trans. 1 1979, 1455-1458; (b) Ferrier, R.; Middleton, S. Chem. Rev. 1993, 93, 2779-2831; (c) Dalko, P.; Sinaÿ, P. Angew. Chem., Int. Ed. 1999, 38, $773-$ 777; (d) Sollogoub, M.; Mallet, J.-M.; Sinaÿ, P. Angew. Chem., Int. Ed. 2000, 39, 362-364.

(C) 2005 by MDPI (http://www.mdpi.org). Reproduction is permitted for noncommercial purposes. 